\title{
Metal-sulfide complexation in seawater
}

\author{
Radwan Al-Farawati, Constant M.G. van den Berg * \\ Oceanography Laboratory, Department of Earth Science, University of Liverpool, Liverpool L69 3BX, UK
}

Received 16 September 1997; revised 9 June 1998; accepted 18 June 1998

\begin{abstract}
The conditional stability constants of metal-sulfide complexes were determined in $\mathrm{pH} 8$ seawater at various salinities, by flow-analysis with detection by cathodic stripping voltammetry (FA-CSV). Two methods were used. The first method was titration of the sulfide by metal with detection of the free sulfide by FA-CSV. The titrant metals were $\mathrm{Ag}^{+}, \mathrm{Cd}^{2+}, \mathrm{Co}^{2+}$, $\mathrm{Fe}^{2+}, \mathrm{Mn}^{2+}, \mathrm{Pb}^{2+}, \mathrm{Zn}^{2+}, \mathrm{Cr}^{3+}$ and $\mathrm{Al}^{3+}$. This method was suitable for comparatively weak complexes $(\log K<\sim 8)$. The second method took advantage of ligand competition between sulfide and 8-hydroxyquinoline (oxine) for free metal ions. The ability of the oxine to form electroactive complexes with $\mathrm{Cu}^{2+}, \mathrm{Cd}^{2+}, \mathrm{Pb}^{2+}, \mathrm{Zn}^{2+}, \mathrm{Co}^{2+}$ and $\mathrm{Ni}^{2+}$, was used to detect the concentration of the metal-oxine complexes in equilibrium with sulfide. More stable complexes could be detected by this method. The two independent methods could be compared for some metals showing good agreement. The stability of the sulfide complexes with copper was found to be much greater than previously determined, in line with theoretical prediction. The high stability, greater than that for $\mathrm{Ag}^{+}$, suggests that copper may be complexed by sulfide as copper(I) rather than copper(II). Complex stability with $\mathrm{Co}^{2+}$ and $\mathrm{Cd}^{2+}$ is also greater than found before, but the difference is smaller. The stability constants were used to calculate the speciation of sulfide at realistic sulfide and metal concentrations similar to those present in the open ocean. At a sulfide concentration of $0.5 \mathrm{nM}$ and a copper concentration of $1 \mathrm{nM}$ in seawater, the major form of sulfide is copper(II) monobisulfide $\left(\mathrm{Cu}(\mathrm{HS})^{+}\right)$representing $99 \%$ of the total sulfide. In the presence of natural organic complexing ligands a smaller percentage $(28 \%)$ of sulfide was bound to copper, the remainder occurring as bisulfide, whereas copper was then $71 \%$ complexed by organic matter. The new data and the calculations confirm the potential importance of sulfide as a complexing ligand in seawater, more important than major anions and competing effectively with natural organic ligands. (C) 1999 Elsevier Science B.V. All rights reserved.
\end{abstract}

Keywords: metal-sulfide complexes; seawater; cathodic stripping voltammetry; flow analysis

\section{Introduction}

Sulfide is known to occur in anoxic environments where the rate of oxygen removal is close to or

\footnotetext{
* Corresponding author. Tel.: +44-151-794-4096; Fax: +44151-794-4099; E-mail: sn35@liv.ac.uk
}

exceeds its rate of supply. In such environments (e.g., the Black Sea and Framvaren Fjord), the residual oxygen concentration is present at low or non-detectable levels. At these levels sulfate is used by anaerobic bacteria as an electron acceptor, leading to the reduction of sulfate to sulfide. Anoxic environments are highly dynamic regions, and remarkable variations in the dissolved concentration of trace metals have been found at the oxic-anoxic boundary 
in anoxic lakes (Davison and Heaney, 1978; Morfett et al., 1988; Balistrieri et al., 1992, 1994; Achterberg et al., 1997), and anoxic marine waters (Emerson and Jacobs, 1982; Kremling, 1983; Jacobs et al., 1985; Dyrssen and Kremling, 1990).

The improvement in sensitivity of analytical techniques since the mid-1970s has increased our knowledge of the distribution and speciation of the trace metals in seawater (Bruland, 1983). Voltammetry is a powerful tool to study trace metal speciation (e.g., Duinker and Kramer, 1977; Hasle and Abdullah, 1981; Nürnberg and Valenta, 1983; Donat and Bruland, 1990; Campos and van den Berg, 1994; Gledhill and van den Berg, 1994; van den Berg et al., 1994), and has been used before to determine stability constants of metal-sulfide complexes in seawater (Zhang and Millero, 1994; Luther et al., 1996). However, the preconcentration of complex species on an electrode to which a potential is applied can alter the speciation in the diffusion layer if the experimental set-up is not carefully considered. Its effect on the redox speciation of studied metals is not yet fully appreciated and may explain variations in results.

Awareness of the potential importance of sulfide to metal speciation has increased due to evidence suggesting the presence of sulfide in oxic seawater as measured by two techniques: gas chromatography (Cutter and Krahforst, 1988; Radford-Knoery and Cutter, 1993, 1994) and CSV (Luther and Tsamakis, 1989). The hydrolysis of carbonyl sulfide is thought to be the main source of sulfide, at pico to nanomolar concentration, in seawater (Elliott et al., 1987). Sulfide in seawater is thought to be oxidized by several oxidants including oxygen (Millero, 1991), hydrogen peroxide (Millero et al., 1989), and iodate (Zhang and Whitfield, 1986), and its presence is therefore unexpected. Sulfide is thought to be stabilised by complexation with trace metals (Luther and Tsamakis, 1989). Several metals have been proposed as responsible for the sulfide stabilisation. Estimation of the stability of metal-sulfide complexes using the linear free energy technique suggests that sulfide speciation in seawater is controlled by copper (Dyrssen, 1988; Elliott, 1988).

Experimental work on the rate of sulfide oxidation by metals demonstrated that copper(II) monobisulfide has a higher oxidation rate than free sulfide, and that $\mathrm{Zn}^{2+}$ is more likely to stabilise sulfide (Vazquez et al., 1989). Voltammetry was used to monitor the distribution of sulfide in the water column of the Black Sea (Luther et al., 1991). A distinction was made between free and complexed sulfide, depending on the location of the peak potential, and it was postulated that the complexed sulfide was in the form of manganese sulfide $(\mathrm{MnS})$ at depths below $100 \mathrm{~m}$. A polarographic peak (at -1.1 V) of sulfide species in anoxic lake waters in the presence of iron(II) and a high level of sulfide was attributed to iron(II) sulfide (FeS) (Davison, 1977b). Iron(II) sulfide species are also thought to occur at the sulfidic-nonsulfidic interface in marine porewaters (Luther and Ferdelman, 1993). The sulfide in lake waters can be loosely attached to algae (Davison and Gabbutt, 1979). The iron(II) sulfide complexes are kinetically labile when their interaction is determined in standard solutions contain iron(II) and sulfide, whereas these complexes are inert in porewaters (Luther and Ferdelman, 1993).

Although free sulfide can be determined by CSV its determination suffers from problems because several thiol compounds, and perhaps also metal complexes of sulfide, give a peak indiscernible from that for free sulfide. A recent study (Ciglenecki and Cosovic, 1996) has shown that the voltammetric response to a sulfide-like compound in seawater gave a stable voltammetric peak even after acidification and purging, suggesting that it was not due to free sulfide. More recently, the sulfide-like peak in seawater has been ascribed to thiols (Al-Farawati and van den Berg, 1997). It is therefore possible that the free sulfide concentration in the marine system is lower than expected, and that part of the voltammetric response is due to thiols.

On the whole the previous work indicates the presence of free sulfide, various metal-sulfide species, as well as sulfide-like substances in freshwater and seawater. For modeling purposes it is important to establish the thermodynamic stability of the major metal-sulfide species. The stability of the sulfide-metal species has been evaluated theoretically (Dyrssen, 1988), and experimentally (Zhang and Millero, 1994; Luther et al., 1996) by voltammetry. Recent work has shown that the sulfide peak obtained by conventional CSV is unstable due to precipitation with mercury which usually is present 
in the voltammetric cell (Al-Farawati and van den Berg, 1997). This problem is eliminated by using FA-CSV instead of the conventional, batch-wise, voltammetric analysis. FA-CSV is used here to determine complexation of sulfide with several trace metals in seawater. The constants were determined at slightly higher than normal ambient sulfide (ranging between nanomolar and micromolar levels) and metal (low to high nanomolar levels) concentrations, and the seawater has been treated to remove possible interfering organic matter. The methods and the results are presented here. As before (Dyrssen, 1988), it is assumed in this work that the metal species are complexed with bisulfide as this is much more predominant than sulfide; our methods do not allow to differentiate between sulfide and bisulfide species but, for reasons of comparison, the constants could be readily converted to a free sulfide scale by taking protonation into account.

\section{Theory and calculations}

Two methods were used to determine the stability of the metal-sulfide species, the first based on detection of free sulfide in the presence of added metal ions, and the second based on ligand competition with detection of the residual metal concentration in the presence of added sulfide.

Hydrogen sulfide dissociates as follows:

$\mathrm{H}_{2} \mathrm{~S} \Leftrightarrow \mathrm{H}^{+}+\mathrm{HS}^{-}$

$\mathrm{HS}^{-} \Leftrightarrow \mathrm{H}^{+}+\mathrm{S}^{2-}$

where $\left[\mathrm{H}_{2} \mathrm{~S}\right]$ is the concentration of hydrogen sulfide, $\left[\mathrm{HS}^{-}\right]$is the concentration of the bisulfide ion, and $\left[\mathrm{S}^{2-}\right]$ is the concentration of the sulfide ion.

The mass balance for sulfide is expressed as:

$$
[\mathrm{S}]_{\mathrm{T}}=\left[\mathrm{H}_{2} \mathrm{~S}\right]+\left[\mathrm{HS}^{\cdot}\right]+\left[\mathrm{S}^{2-}\right]
$$

where $[S]_{\mathrm{T}}$ is the total concentration of sulfide (including bisulfide) species. Using a value of 6.67 (Hershey et al., 1988) for $\mathrm{p} K_{1}$ (Eq. (1)) and 13.6 (Goldhaber and Kaplan, 1975) for $\mathrm{p} K_{2}$ (Eq. (2)), the fractions of sulfide species at $\mathrm{pH} 8$ seawater are $4.46 \%, 95.53 \%$ and $2.5 \times 10^{-4} \%$ for $\mathrm{H}_{2} \mathrm{~S}, \mathrm{HS}^{-}$and
$\mathrm{S}^{2-}$, respectively. It can therefore be approximated that

$[\mathrm{S}]_{\mathrm{T}} \approx\left[\mathrm{HS}^{\prime}\right]$

and, in the absence of metals,

$[\mathrm{HS}]_{\mathrm{T}}=\left[\mathrm{HS}^{-}\right]$

where $[\mathrm{HS}]_{\mathrm{T}}$ is the total bisulfide ion concentration.

\subsection{Method of free sulfide detection}

(Bi-)sulfide is detected by CSV due to its reaction with mercury:

$\mathrm{HS}^{-}+\mathrm{Hg} \leftrightarrow \mathrm{HgS}+\mathrm{H}^{+}+\mathrm{e}^{-}$

During the deposition step, at a potential more positive than that of the 'sulfide' reduction peak this reaction goes to the right as sulfide is concentrated on the electrode. During the CSV scan the mercury in the precipitated (or adsorbed) species is oxidised and the reaction goes back to the left. The peak is therefore a mercury reduction peak, not a sulfide reduction peak. The peak height is directly dependent on the concentration of free sulfide, and on a contribution of sulfide which is released from metal-sulfide species dissociating in the diffusion layer depending on the decrease of the free sulfide concentration at the electrode surface during the deposition step and on the dissociation kinetics of metal-sulfide species.

The voltammetric signal for sulfide in the absence of added metal $\left(I_{\max }\right)$ corresponds with the total sulfide concentration. Complexation of $\mathrm{HS}^{-}$by the major cations in seawater is likely, but its effect is constant. The term $\left[\mathrm{HS}^{\prime}\right]$ is used instead of $\left[\mathrm{HS}^{-}\right]$to denote the concentration of bisulfide not complexed by trace metals in seawater, comprising free bisulfide and bisulfide complexed by the major cations. In the absence of added metals:

$[\mathrm{HS}]_{\mathrm{T}}=\left[\mathrm{HS}^{\prime}\right]$

After addition of metal to seawater with added sulfide, the signal corresponding to sulfide decreases 
as a result of metal-sulfide complex formation. The reaction of metal with sulfide is expressed as:

$\mathrm{M}^{n+}+m \mathrm{HS}^{-}=\left(\mathrm{M}(\mathrm{HS})_{m}\right)^{(n-m)+}$

The conditional stability constant, $\beta_{m}^{\prime}$ is

$\beta_{m}^{\prime}=\frac{\left[\mathrm{M}(\mathrm{HS})_{m}\right]^{(n-m)+}}{\left[\mathrm{M}^{n+}\right]\left[\mathrm{HS}^{\prime}\right]^{m}}$

Where $\left[\mathrm{M}^{n+}\right]$ is the free metal concentration, and $\left[\mathrm{M}(\mathrm{HS})_{m}\right]^{(n-m)+}$ is the concentration of metalsulfide species. It is implicitly assumed here that the metal-sulfide species are of the bisulfide-type.

Rearrangement of Eq. (7) yields:

$\left[\mathrm{M}(\mathrm{HS})_{m}\right]^{(n-m)+}=\beta_{m}^{\prime}\left[\mathrm{M}^{n+}\right]\left[\mathrm{HS}^{\prime}\right]^{m}$

The sulfide signal decreases when metal is added due to complex formation with the added metal ions. In this case, the current is denoted as $I_{\mathrm{P}, \mathrm{S}}$. The mass balance for sulfide is:

$\| \mathrm{HS}]_{\mathrm{T}}=\left[\mathrm{HS}^{\prime}\right]+[\mathrm{MHS}]_{\mathrm{T}}$

where $[\mathrm{MHS}]_{\mathrm{T}}$ is the total concentration of metalsulfide species:

$[\mathrm{MHS}]_{\mathrm{T}}=\sum m\left[\mathrm{M}(\mathrm{HS})_{m}\right]^{n-m+}$

Combining Eqs. (8)-(11) yields:

$[\mathrm{HS}]_{\mathrm{T}}=\left[\mathrm{HS}^{\prime}\right]+\sum m \beta_{m}^{\prime}\left[\mathrm{M}^{n+}\right]\left[\mathrm{HS}^{\prime}\right]^{m}$

The ratio $(R)$ of free over total sulfide is accessible by CSV. Its relationship to the sulfide speciation is derived from Eq. (12):

$R=\frac{\left[\mathrm{HS}^{\prime}\right]}{[\mathrm{HS}]_{\mathrm{T}}}=\frac{1}{1+\sum m \beta_{m}^{\prime}\left[\mathrm{M}^{n+}\right]\left[\mathrm{HS}^{\prime}\right]^{m-1}}$

Voltammetrically the ratio $R=$ (free sulfide/total sulfide) is obtained from:

$R=\frac{\left[\mathrm{HS}^{\prime}\right]}{[\mathrm{HS}]_{\mathrm{T}}}=\frac{I_{\mathrm{P}, \mathrm{S}}}{I_{\max }}$

which is determined experimentally from the ratio of the voltammetric response for sulfide in the presence $\left(I_{\mathrm{P}, \mathrm{S}}\right)$ and absence $\left(I_{\max }\right)$ of added metals. In the absence of added metals $I_{\mathrm{P}, \mathrm{S}}=I_{\max }$ and the ratio
$R=1$. The free metal ion concentration $\left[\mathrm{M}^{n+}\right]$ is computed from the mass balance for the metal:

$[\mathrm{M}]_{\mathrm{T}}=\left[\mathrm{M}^{\prime}\right]+[\mathrm{MHS}]_{\mathrm{T}}$

where $[M]_{T}$ is the total metal concentration, and $\left[\mathrm{M}^{\prime}\right]$ is the metal concentration not complexed by sulfide including complexes with the major anion in seawater:

$\left[\mathrm{M}^{\prime}\right]=\left[\mathrm{M}^{n+}\right] \alpha_{\mathrm{M}}$

where $\alpha_{\mathrm{M}}$ is the side-reaction coefficient of the metal in seawater. $\alpha_{\mathrm{M}}$ is defined as:

$\alpha_{\mathrm{M}}=1+\sum K_{i j} *\left[F_{j}\right]^{i}+\sum \frac{K_{\mathrm{a}, i} *}{\left[\mathrm{H}^{+}\right]^{i}}$

where $K_{i j} *$ is the stepwise stability constant of $\mathrm{M}^{n+}$ with each major anion $F_{j}$, and $K_{\mathrm{a}, i} *$ is the stepwise acidity constant. $\alpha_{\mathrm{M}}$ was calculated for each metal using an ion-pairing model to obtain free major anion concentrations, and using stability constants valid for seawater from (Turner et al., 1981). These constants are 'concentration constants' corrected for the salinity (and ionic strength) of seawater using interpolation equations, so concentrations rather than activities are used throughout. The free metal ion is then obtained from:

$\left[\mathrm{M}^{n+}\right]=\frac{[\mathrm{M}]_{\mathrm{T}}-[\mathrm{MHS}]_{\mathrm{T}}}{\alpha_{\mathrm{M}}}$

The total metal concentration is known as it was added to seawater. $[\mathrm{MHS}]_{\mathrm{T}}$ was determined experimentally from the difference of the added total sulfide concentration and the residual free sulfide concentration as measured by FA-CSV.

Values for conditional stability constants were calculated by curve-fitting of $R$ as a function of $\left[\mathrm{M}^{n+}\right]$ to Eq. (13); preliminary values for $\beta_{m}^{\prime}$ were calculated (and averaged) from individual values of $R$ using the following modified Eq. (13):

$\beta_{m}^{\prime}=\frac{\frac{1}{R}-1}{\sum m\left[\mathrm{M}^{n+}\right]\left[\mathrm{HS}^{m-1}\right]}$

These values were used as initial values in the curve-fitting program.

\subsection{Ligand competition method}

This method depends on competition between sulfide and oxine for metal ions. Oxine forms a 
complex with the metal which is detected by FACSV. After addition of sulfide, the signal of the metal-oxine complex decreases as a result of complexation of the metal by sulfide. The procedure is similar to that used for the CSV methods to determine complexation of zinc, nickel, and copper, by organic complexing ligands in seawater using ligand competition against APDC (ammonium pyrrolidine dithiocarbamate) (van den Berg, 1985), DMG (dimethyl glyoxime) (van den Berg and Nimmo, 1987) and tropolone (Donat and van den Berg, 1992), respectively.

The measured reduction current, $I_{p}$, is directly related to the dissolved concentration of metal-oxine, [Moxine ${ }_{j}$ ] through a proportionality factor $S_{1}$ :

$I_{p}=S_{1}\left[\right.$ Moxine $\left._{j}\right]$

where $j=1,2,3$, etc. The reduction current $I_{p}$ is directly related to the labile metal concentration via the sensitivity which is calibrated by means of standard metal additions in the absence of sulfide. The labile metal concentration is then defined as all metal not complexed by sulfide, comprising [Moxine ${ }_{j}$ ] and metal complexes with the major anions in seawater. The relationship between the free metal ion and the labile metal concentration is given by

$\left[\mathrm{M}^{n+}\right]=[$ labile metal $] /\left(\alpha_{\mathrm{M}-\text { oxine }}+\alpha_{\mathrm{M}}\right)$

In the absence of added sulfide the measured reduction current is maximal so:

$I_{p}=I_{\max }$

and

$\left[\right.$ Moxine $\left._{j}\right]=\left[\mathrm{M}^{n+}\right] \alpha_{\mathrm{M}-\text { oxine }}$

where $\alpha_{\mathrm{M} \text {-oxine }}$ is $\alpha$-coefficient for the complexation of metal by oxine.

$\alpha_{\mathrm{M}-\text { oxine }}=\beta_{\mathrm{M}-\text { oxine }}^{\prime}\left[\text { oxine }^{\prime}\right]^{j}$

where [oxine'] is the oxine concentration not complexed by the metal (the total oxine concentration [oxine $_{\mathrm{T}}$ was used instead of [oxine' $]$ as $[\text { oxine }]_{\mathrm{T}} \gg$ $[\mathrm{M}]_{\mathrm{T}}$ ) and $\beta_{\mathrm{M} \text {-oxine }}^{\prime}$ is the conditional stability constant of each metal-oxine complex. Values for the conditional stability constants $\beta_{\mathrm{M} \text {-oxine }}^{\prime}$ were calculated from the thermodynamic stability constant
$\beta_{\mathrm{M} \text {-oxine }} *$ by correction for side reactions of oxine with the major cations and hydrogen ions in seawater:

$\beta_{\mathrm{M}-\text { oxine }} *=\frac{\left[\text { Moxine }_{j}\right]}{\left[\mathrm{M}^{n+}\right]\left[\text { oxine }^{-}\right]^{j}}$

where $\left[\right.$ oxine $^{-}$] is the free oxine concentration which is correlated to [oxine' $]$ by:

oxine $\left.^{-}\right]=\frac{\left[\text { oxine }^{\prime}\right]}{\alpha_{\text {oxine }}}$

where $\alpha_{\text {oxine }}$ is the side reaction coefficient of oxine with hydrogen ion and major cations in seawater. $\alpha_{\text {oxine }}$ was calculated from the relation:

$\alpha_{\text {oxine }}=1+\sum K_{i} *\left[\mathrm{~J}^{n+}\right]^{i}+\sum \frac{\left[\mathrm{H}^{+}\right]^{i}}{K_{\mathrm{a}, i} *}$

where $K_{i} *$ is the stepwise stability constant of oxine with $\mathrm{J}, K_{\mathrm{a}, i} *$ is the stepwise acidity constant, $\left[\mathrm{J}^{n+}\right]$ is the concentration of free cations in seawater, and $\left[\mathrm{H}^{+}\right]$is the free hydrogen ion concentration. Values for $\left[\mathrm{J}^{n+}\right]$ and $\left[\mathrm{H}^{+}\right]$were calculated using an ion-pairing model using data from Dickson and Whitfield (1981) and Dickson and Millero (1987).

Substitution of Eq. (24) in Eq. (23) yields:

$\beta_{\mathrm{M}-\text { oxine }} *=\frac{\left[\text { Moxine }_{j}\right]}{\left[\mathrm{M}^{n+}\right] \frac{\left[\text { oxine }^{\prime}\right]^{j}}{\alpha_{\text {oxine }}}}$

which is equivalent to

$\beta_{\mathrm{M}-\text { oxine }}^{\prime}=\frac{\beta_{\mathrm{M}-\text { oxine }} *}{\alpha_{\text {oxine }}}$

In the absence of sulfide all metal is labile, and $[\mathrm{M}]_{\mathrm{T}}$ is related to $\left[\mathrm{M}^{n+}\right]$ by:

$[\mathrm{M}]_{\mathrm{T}}=\left[\mathrm{M}^{n+}\right]\left[\alpha_{\mathrm{M}}+\alpha_{\mathrm{M}-\text { oxine }}\right]$

In the presence of sulfide the current is diminished by the amount of metal complexed by sulfide:

$I_{\mathrm{P}, \mathrm{S}}=S_{1}\left[\text { Moxine }_{j}\right]_{\mathrm{S}}$

where $[\text { Moxine }]_{S}$ indicates the concentration of metal-oxine species in the presence of sulfide:

$\left[\text { Moxine }_{j}\right]_{\mathrm{S}}=\left[\mathrm{M}^{n+}\right]_{\mathrm{S}} \alpha_{\mathrm{M}-\text { oxine }}$ 
The mass balance for the metal in the presence of sulfide is written as:

$$
[\mathrm{M}]_{\mathrm{T}}=\left[\mathrm{M}^{n+}\right]_{\mathrm{S}}\left[\alpha_{\mathrm{M}}+\alpha_{\mathrm{M}-\text { axine }}+\alpha_{\mathrm{MHS}}\right]
$$

where $\alpha_{\mathrm{MHS}}$ is $\alpha$-coefficient for the complexation of metal by sulfide:

$$
\alpha_{\mathrm{MHS}}=\beta_{m}^{\prime}\left[\mathrm{HS}^{\prime}\right]^{m}
$$

The ratio, $Q$, of the peak current in the presence $\left(I_{\mathrm{P}, \mathrm{S}}\right)$ over that in the absence $\left(I_{\max }\right)$ of sulfide $\left(Q=I_{\mathrm{P}, \mathrm{S}} / I_{\max }\right)$ is directly related to the concentrations of the metal-oxine species in those conditions:

$Q=I_{\mathrm{P}, \mathrm{S}} / I_{\max }=S_{1}\left[\text { Moxine }_{j}\right]_{\mathrm{S}} / S_{1}\left[\right.$ Moxine $\left._{j}\right]$.

After substitution and simplification this ratio is directly related to the free metal concentrations in the presence and absence of sulfide:

$$
Q=\frac{\left[\mathrm{M}^{n+}\right]_{\mathrm{S}}}{\left[\mathrm{M}^{n+}\right]}
$$

Substitution for $\left[\mathrm{M}^{n+}\right]$ and $\left[\mathrm{M}^{n+}\right]_{\mathrm{S}}$ using Eqs. (28) and (31) with rearrangement gives

$$
Q=\frac{\alpha_{\mathrm{M}}+\alpha_{\mathrm{M}-\text { oxine }}}{\alpha_{\mathrm{M}}+\alpha_{\mathrm{M}-\text { oxine }}+\alpha_{\mathrm{MHS}}}
$$

This means that the ratio $(Q)$ of the peak heights depends on a relatively simple ratio of $\alpha$-coefficients. $Q$ is directly accessible by experiment. $Q$ varies when $\alpha_{\mathrm{MHS}}$ (the only unknown) is varied by sulfide addition. The other $\alpha$-coefficients are constant during each experiment.

Substitution for $\alpha_{\mathrm{MHS}}$ in Eq. (34) yields:

$Q=\frac{\alpha_{\mathrm{M}}+\alpha_{\mathrm{M}-\text { oxine }}}{\alpha_{\mathrm{M}}+\alpha_{\mathrm{M}-\text { oxine }}+\beta_{m}^{\prime}\left[\mathrm{HS}^{\prime}\right]^{m}}$

$\left[\mathrm{HS}^{\prime}\right]$ is calculated from a sulfide mass balance:

$$
\left[\mathrm{HS}^{\prime}\right]=[\mathrm{HS}]_{\mathrm{T}}-\left[[\mathrm{M}]_{\mathrm{T}}-[\mathrm{M}]_{\text {labile }}\right]
$$

where $[\mathrm{M}]_{\text {labile }}$ is the labile metal concentration which is measured by FA-CSV; and the total sulfide and metal concentrations are known (the metal initially present in the seawater was determined by CSV and was included in the total metal concentrations). Values for $\beta_{m}^{\prime}$ were obtained by fitting $Q$ to Eq. (35) using non-linear, least square curve-fitting as a function of the sulfide concentration.

Preliminary values for $\beta_{m}^{\prime}$ were obtained by calculation of single values from:

$\beta_{m}^{\prime}=\frac{\left[\frac{\alpha_{\mathrm{M}}+\alpha_{\mathrm{M}-\text { oxine }}}{Q}\right]-\left[\alpha_{\mathrm{M}}+\alpha_{\mathrm{M}-\text { oxine }}\right]}{\left[\mathrm{HS}^{\prime}\right]^{m}}$

\section{Materials and methods}

\subsection{Equipment}

Voltammetric measurements of sulfide and metals were performed by FA-CSV using an Autolab voltammeter (Eco Chemie) that was interfaced with a Metrohm 663 VA electrode stand and a hanging mercury drop electrode (HMDE). The conventional voltammetric cell was replaced by a specially designed flow-cell which was fitted in the bottom of a voltammetric cell made from extruded acrylic (AlFarawati and van den Berg, 1997). For some metals (Ni, $\mathrm{Zn}$ and $\mathrm{Co}$ ) the flow cell was preceded by an in-line deaeration system (Colombo et al., 1997) to remove dissolved oxygen. The in-line deaeration system consisted of a length of silicone tubing $(1 \mathrm{~m})$ which was fitted inside a $28 \mathrm{ml}$ container which was

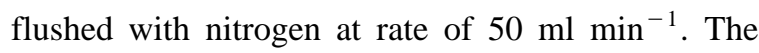
reference electrode was double-junction: an $\mathrm{Ag} / \mathrm{AgCl} / 3 \mathrm{M} \mathrm{KCl}$ reference cartridge (Metrohm, Switzerland) was separated by a frit from a salt bridge filled with $3 \mathrm{M} \mathrm{KCl}$ : the bridge was freshly filled with $\mathrm{KCl}$ solution at the beginning of the experiments. The counter electrode was a glassy carbon rod. UV-digestion was carried out using a 1 $\mathrm{kW}$, high-pressure, mercury vapour lamp.

\subsection{Reagents}

Water for preparation of reagents and rinsing was purified by reverse osmosis (Milli-RO, Millipore) and ion-exchange (Milli-Q, Millipore). Acid ( $\mathrm{HCl}$ ) and ammonia used for solutions were purified by sub-boiling, quartz distillation. Stock solutions of 0.1 $\mathrm{M}$ NaHS were prepared daily from $\mathrm{Na}_{2} \mathrm{~S} \cdot 9 \mathrm{H}_{2} \mathrm{O}$ (Aldrich) in Milli-Q. Metal stock solutions were prepared by dilution of atomic absorption spectrome- 
try standard solutions (BDH, Spectrosol grade) in Milli-Q and acidified by addition of $10 \mu \mathrm{l}$ of $50 \%$ $\mathrm{HCl}$ to $10 \mathrm{ml}$ of solution. Standard of $\mathrm{Fe}(\mathrm{II})$ and $\mathrm{Mn}$ (II) were prepared from $\mathrm{Fe}$ (III) and $\mathrm{Mn}$ (II) in an aqueous solution of hydroxylammonium hydrochloride at a concentration 10 times higher than that of the iron and manganese to maintain the iron and manganese in reduced form. A stock solution of 0.1 $\mathrm{M}$ hydroxylammonium hydrochloride (Analar, BDH) was prepared prior to use in Milli-Q. A stock solution of $5 \mathrm{M}$ sodium nitrite (Analar, BDH) was prepared in Milli-Q. Hydrochloric acid was Analar (BDH) grade. A stock solution of 0.1 M 8-hydroxyquinoline (oxine), (BDH, Analar) was prepared in $0.2 \mathrm{M} \mathrm{HCl}$ and diluted with Milli-Q; this solution is stable for several months (van den Berg, 1986). A $\mathrm{pH}$ buffer was prepared by containing $1 \mathrm{M}$ tris(hydroxymethyl)methylamine (Analar, BDH) in $0.5 \mathrm{M}$ $\mathrm{HCl}$; addition of $100 \mu \mathrm{l}$ of this TRIS buffer in $10 \mathrm{ml}$ seawater served to maintain the $\mathrm{pH}$ at 8 . A solution of $2 \mathrm{M} \mathrm{NH}_{3} / \mathrm{NH}_{4}^{+}$was prepared by mixing ammonia with hydrochloric acid, and was used to buffer the $\mathrm{pH}$ at 9 during voltammetric detection of cobalt to improve the sensitivity.

Seawater used throughout the experiments originated from the North Sea, and had a salinity of 35 . The water was UV-irradiated for $3 \mathrm{~h}$ to eliminate organic matter that could interfere with the metalsulfide complexation measurements. This water was diluted with UV-irradiated Milli-Q water to obtain lower salinities of 21 and 10.5. All reagent solutions were prepared by weighing the solid and Milli-Q into pre-cleaned polystyrene $(30 \mathrm{ml})$ (Bibby Sterilin, Cat. No. 128A) tubes (called Sterilins in the text), or Nalgene high density polyethylene bottles. The final volume of the solutions was adjusted by weight. This procedure for solution preparation avoids possible contamination with metal ions (such as from glassware or due to excessive manipulation of the solutions).

\subsection{Procedure of the free sulfide detection method}

About $100-150 \mathrm{ml}$ of irradiated seawater was transferred to a $250 \mathrm{ml}$ polyethylene bottle and buffered with Tris to $\mathrm{pH} 8$. A subsample of $10 \mathrm{ml}$ was pipetted into a clean Sterilin, and sulfide was added. This aliquot was used as reference (without added metal) to calculate the ratio, $R$ (Eq. (13)).
Metal was added to a second, third, fourth and so on (with increasing metal concentrations), aliquot, and the free sulfide concentration was determined by FA-CSV. The analysis was initiated within $1 \mathrm{~min}$ after sulfide addition. This procedure continued with increasing metal concentrations of metal, until the peak height of sulfide was reduced to approximately a third of the peak height of the reference sample. $\mathrm{pH}$ changes by additions of some metal solutions (Al(III) and $\mathrm{Cr}(\mathrm{III})$ ) caused the sulfide peak to shift to a more positive potential due to acid in these solutions $(0.5 \mathrm{~N}$ of nitric acid for $\mathrm{Al}$ and $0.1 \mathrm{~N}$ of perchloric acid for $\mathrm{Cr}$ ). Ammonia was therefore added along with the $\mathrm{Al}$ and $\mathrm{Cr}$ additions to neutralize the $\mathrm{pH}$ effect.

\subsection{Procedure of the ligand competition method}

A total of $100-150 \mathrm{ml}$ of the UV-irradiated seawater was transferred to a $250 \mathrm{ml}$ polyethylene bottle. The seawater was buffered to $\mathrm{pH} 8$ by addition of Tris buffer for cadmium, copper, lead, nickel and zinc, and $\mathrm{pH} 9$ by addition of ammonium buffer for cobalt. Oxine $(1-100 \mu \mathrm{M})$ and metal additions (30-100 nM) were made to the buffered seawater. A subsample of $10 \mathrm{ml}$ was pipetted into a clean Sterilin, spiked with the sulfide standard and mixed. After an equilibration time of 1-2 min, the peak height of the metal-oxine was measured by FA-CSV. The pump was run for 2 min prior to initiating the measurements between different concentrations allowing the tubing to become flushed with new sample solution. Between four and six scans were carried out at each concentration. The procedure continued with increasing concentrations of sulfide until the peak height of the metal was reduced to $\sim 30 \%$ of the initial peak height before the sulfide additions. The voltammetric parameters to determine the stability constants of metal-sulfide complexes are shown in Table 1.

\subsection{In-line purging}

In-line purging was used for the voltammetric determination of the cobalt, nickel and zinc concentrations, as the oxygen wave was found to interfere. The oxygen wave was a broad peak occurring at $\sim-1 \mathrm{~V}$, overlapping with the peak potentials for the oxine complexes with nickel, zinc and cobalt, at 
Table 1

The experimental parameters for determination of metal-sulfide complexation using cathodic stripping voltammetry. The methods are indicated by FS (free sulfide detection) or LC (ligand competition)

\begin{tabular}{|c|c|c|c|c|c|}
\hline Metal & $\begin{array}{l}\text { Deposition } \\
\text { time (s) }\end{array}$ & $\begin{array}{l}\text { Deposition } \\
\text { potential (V) }\end{array}$ & $\begin{array}{l}\text { Frequency } \\
(\mathrm{Hz})\end{array}$ & Scan range $(\mathrm{V})$ & Method \\
\hline$\overline{\operatorname{Ag}(I)}$ & 25 & -0.2 & 200 & -0.4 to -0.9 & FS \\
\hline \multirow[t]{2}{*}{$\mathrm{Cd}(\mathrm{II})$} & 20 & -0.2 & 200 & -0.3 to -0.8 & FS \\
\hline & 20 & -0.2 & 100 & -0.3 to -0.8 & $\mathrm{LC}$ \\
\hline \multirow[t]{2}{*}{$\mathrm{Co}(\mathrm{II})$} & 20 & -0.2 & 200 & -0.3 to -0.8 & FS \\
\hline & 15 & -0.05 & 50 & -0.7 to -1.3 & $\mathrm{LC}$ \\
\hline $\mathrm{Cu}(\mathrm{II})$ & 30 & -0.2 & 100 & -0.2 to -0.8 & $\mathrm{LC}$ \\
\hline $\mathrm{Ni}(\mathrm{II})$ & 30 & -0.1 & 20 & -0.75 to -1.25 & $\mathrm{LC}$ \\
\hline \multirow[t]{2}{*}{$\mathrm{Pb}(\mathrm{II})$} & 20 & -0.2 & 200 & -0.3 to -0.8 & FS \\
\hline & 60 & -0.2 & 100 & -0.3 to -0.8 & $\mathrm{LC}$ \\
\hline \multirow[t]{2}{*}{$\mathrm{Zn}(\mathrm{II})$} & 20 & -0.2 & 200 & -0.3 to -0.8 & FS \\
\hline & 20 & -0.1 & 200 & -0.85 to -1.3 & $\mathrm{LC}$ \\
\hline $\mathrm{Fe}(\mathrm{II})$ & 15 & -0.2 & 200 & -0.3 to -0.8 & FS \\
\hline $\mathrm{Mn}(\mathrm{II})$ & 15 & -0.2 & 200 & -0.3 to -0.8 & FS \\
\hline $\mathrm{Al}(\mathrm{III})$ & 15 & -0.2 & 200 & -0.2 to -0.8 & FS \\
\hline Cr(III) & 15 & -0.2 & 200 & -0.4 to -0.75 & FS \\
\hline
\end{tabular}

$-0.93,-1.11$ and $-1.12 \mathrm{~V}$, respectively. The interference of the oxygen wave with the peaks for the oxine complexes with copper, cadmium, lead and sulfide was much less due to the much better sensitivity for these elements than for oxygen, and also because their peaks occurred away from that for oxygen; the peak potentials for copper, lead, sulfide and cadmium in the presence of oxine were at $-0.40,-0.51,-0.54$ and $-0.67 \mathrm{~V}$, respectively, whilst the background current due to oxygen was low between -0.1 and $-0.9 \mathrm{~V}$. An advantage of measuring without the in-line purging system was a shorter measuring time, because the travel-time of the solution through the tubing was $20 \mathrm{~s}$ less. A titration with sulfide with detection of residual metal took 30-50 min, using 4-6 repeat scans for each aliquot.

\section{Results}

\subsection{Titration of sulfide with metal with detection of free sulfide by FA-CSV}

Voltammetric scans showing the decrease of the sulfide peak by the addition of metal ions are shown for silver in Fig. 1. The sulfide peak is thought to be caused by the reduction of mercuric ions in a precipi- tate of mercuric sulfide species on the electrode surface (e.g., Turner et al., 1975; Luther et al., 1996). In the flow system these species are formed at the electrode surface where bisulfide reacts with metallic mercury. The amount of mercury sulfide deposited is directly related to the free bisulfide concentration at the electrode surface; the peak height

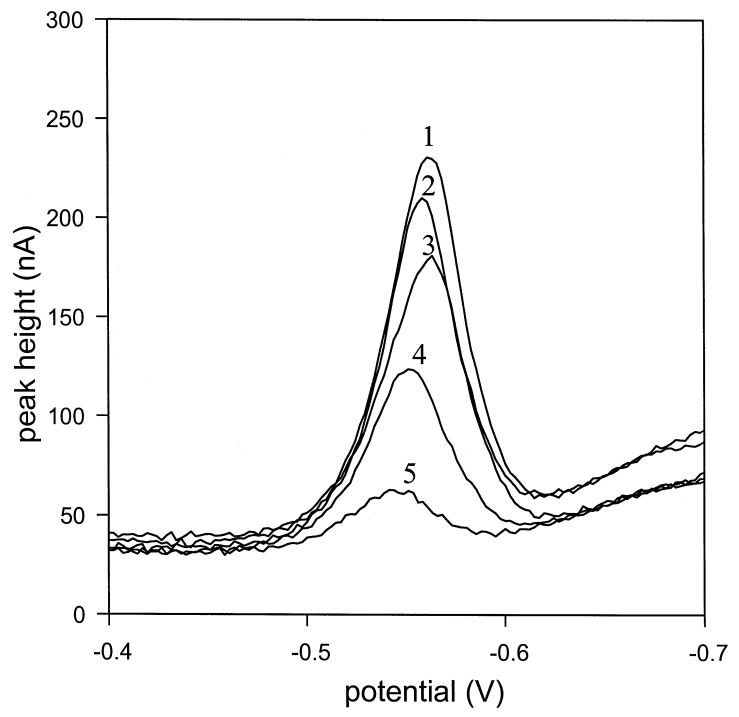

Fig. 1. The voltammetric response of sulfide ion: (1) before addition of silver, and after addition of (2) 100 , (3) 250 , (4) 350 , (5) $2000 \mathrm{nM} \mathrm{Ag}^{+}$, using $100 \mathrm{nM}$ of sulfide ion and salinity of 35. 
is therefore diminished when some of the bisulfide is complexed with competing metal ions. It is possible that some of the dissolved metal-sulfide species (other than mercury) dissociate in the diffusion layer (if they are labile), but their contribution to the dissolved sulfide concentration is likely to be minor until high metal concentrations when most of the sulfide is complexed and the free concentration of sulfide is much lowered. In this work, the titrations of sulfide with metal ions were discontinued when
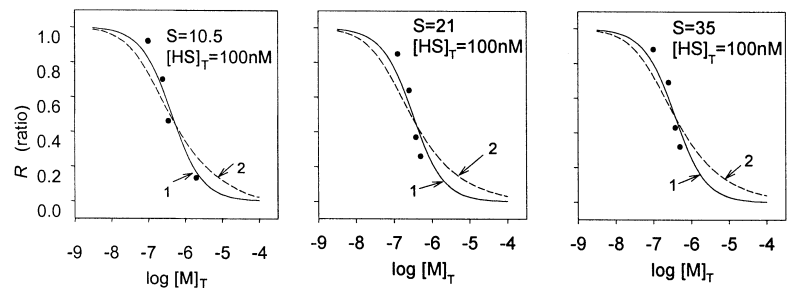

$\mathrm{Ag}$
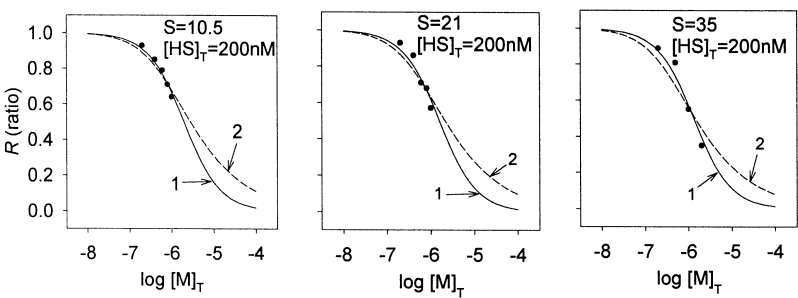

FeII
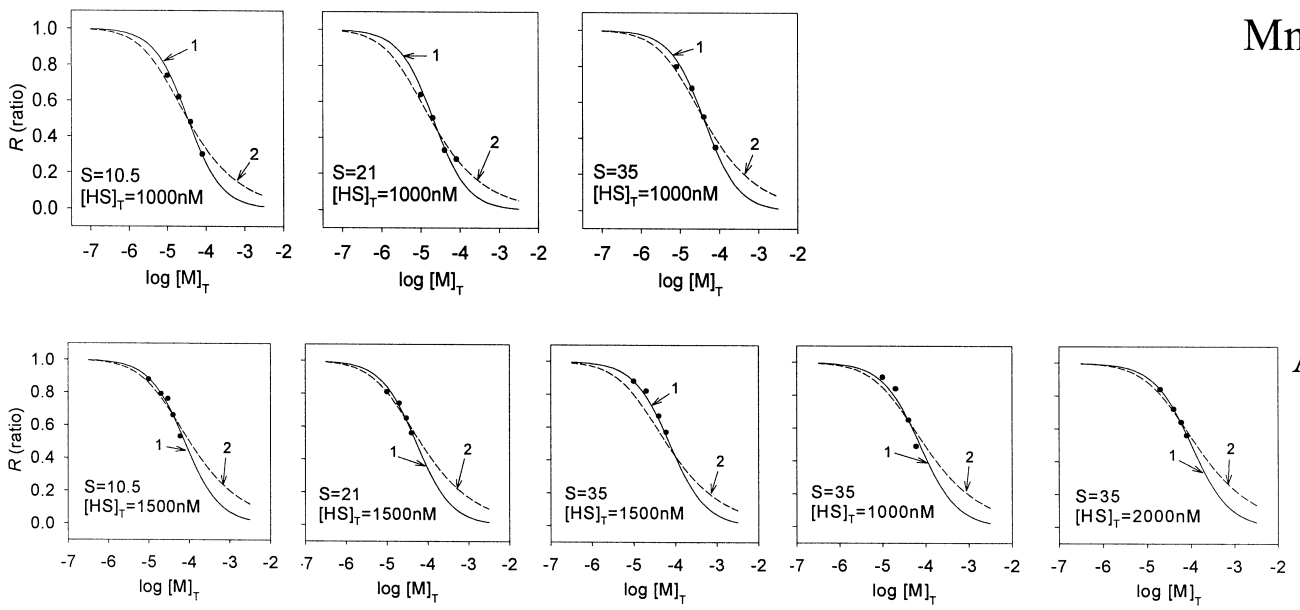

$\mathrm{Al}$
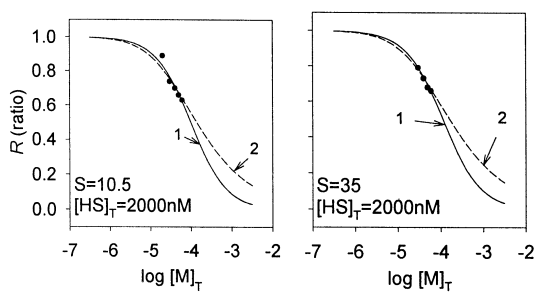

CrIII

Fig. 2. Titration of sulfide with silver, iron(II), manganese(II), aluminum and chromium(III): closed symbols are the data observed; (1) represent the fitting assuming the presence of MHS only or both MHS and M(HS) $)_{2}$ simultaneously; (2) represent the fitting assuming the presence of $\mathrm{M}(\mathrm{HS})_{2}$ only. 
the free sulfide concentration had decreased by 60 $70 \%$, to minimise this possible contribution of the complexed sulfide to the reduction current.

The decrease in the sulfide peak height (the $R$ ratio) with the increase in the metal concentrations is shown in Fig. 2. Values for the stability constants were calculated by non-linear least squares curve fitting of $R$ to Eq. (13); first assuming the presence of only one metal-sulfide species of the type MHS or $\mathrm{M}(\mathrm{HS})_{2}$, and then both simultaneously. Values for the constants were also calculated for each data point separately (Eq. (18)) and averaged. These values were used to corroborate the curve fitting data. The values for the stability constants along with experimental details are presented in Table 2.

\subsection{Titration of metals with sulfide with FA-CSV detection of free metal by ligand competition}

Ligand competition between sulfide and oxine was used to determine the stability constants for sulfide complexes with copper, lead, cadmium, zinc, cobalt and nickel. The complexes of oxine form electroactive species with these metals which can be determined by FA-CSV (van den Berg, 1986; Colombo and van den Berg, 1997). The decrease of the lead-oxine peak upon addition of sulfide is shown in Fig. 3. A peak due to free sulfide appeared at $-0.54 \mathrm{~V}$ when the lead-oxine peak had completely disappeared and all lead had been complexed by the added sulfide. The rather late appearance of the free sulfide peak, at great apparent supersaturation of the dissolved metal concentration, can perhaps be explained by poor sensitivity due to competitive adsorption at high levels of lead-oxine. The same happened with the sulfide titration of cadmium (not shown).

Nioxime and DMG are known to provide high CSV sensitivity for cobalt and nickel in seawater (van den Berg and Nimmo, 1987; Zhang et al., 1990). It was attempted to use nioxime and DMG as

Table 2

Values for conditional stability constants of metal-sulfide complexes determined by measurement of free sulfide and calculated by curve fitting

\begin{tabular}{|c|c|c|c|c|c|c|}
\hline Metal ions & Salinity & Total [HS] (nM) & $\log K_{1}^{\prime}$ & $\log K_{1}^{\prime \prime}$ & $\log \beta_{2}^{\prime}$ & $\log \beta_{2}^{\prime \prime}$ \\
\hline \multirow[t]{3}{*}{$\overline{\mathrm{Ag}^{+}}$} & 35 & 100 & $11.63 \pm 0.10$ & 6.41 & - & - \\
\hline & 21 & 100 & $11.16 \pm 0.11$ & 6.58 & - & - \\
\hline & 10.5 & 100 & $10.46 \pm 0.08$ & 6.65 & - & - \\
\hline $\mathrm{Cd}^{2+}$ & 35 & 20 & $9.13 \pm 0.02$ & 7.58 & - & - \\
\hline $\mathrm{Co}^{2+}$ & 35 & 50 & $6.41 \pm 0.09$ & 6.08 & - & - \\
\hline \multirow[t]{3}{*}{$\mathrm{Fe}^{2+}$} & 35 & 200 & $6.07 \pm 0.06$ & 5.91 & - & - \\
\hline & 21 & 200 & $5.97 \pm 0.04$ & 5.83 & - & - \\
\hline & 10.5 & 200 & $5.86 \pm 0.02$ & 5.73 & - & - \\
\hline \multirow[t]{3}{*}{$\mathrm{Mn}^{2+}$} & 35 & 1000 & $4.51 \pm 0.10$ & 4.28 & $9.93 \pm 0.28$ & 9.70 \\
\hline & 21 & 1000 & $4.59 \pm 0.20$ & 4.42 & $10.57 \pm 0.23$ & 10.40 \\
\hline & 10.5 & 1000 & $4.50 \pm 0.08$ & 4.37 & $9.94 \pm 0.24$ & 9.81 \\
\hline $\mathrm{Pb}^{2+}$ & 35 & 20 & - & - & $16.37 \pm 0.01$ & 14.83 \\
\hline $\mathrm{Zn}^{2+}$ & 35 & 200 & $6.22 \pm 0.24$ & 5.90 & - & - \\
\hline \multirow[t]{5}{*}{$\mathrm{Al}^{3+}$} & 35 & 1500 & $12.97 \pm 0.01$ & 4.09 & - & - \\
\hline & 21 & 1500 & $13.09 \pm 0.02$ & 4.23 & $17.94 \pm 0.71$ & 9.07 \\
\hline & 10.5 & 1500 & $13.01 \pm 0.03$ & 4.12 & - & - \\
\hline & 35 & 1000 & $13.02 \pm 0.05$ & 4.14 & - & - \\
\hline & 35 & 2000 & $12.87 \pm 0.00$ & 3.99 & - & - \\
\hline \multirow[t]{2}{*}{$\mathrm{Cr}^{3+}$} & 35 & 2000 & $9.54 \pm 0.01$ & 3.95 & - & - \\
\hline & 10.5 & 2000 & $9.78 \pm 0.03$ & 4.01 & - & - \\
\hline
\end{tabular}

$K_{1}^{\prime}$ and $\beta_{2}^{\prime}$ are conditional stability constants corrected (using $\alpha_{\mathrm{M}}$ values in Table 4) for side-reactions of the metal but not for those of bisulfide in seawater: $K_{1}^{\prime}=\left[\mathrm{MHS}^{(n-1)+}\right] /\left(\left[\mathrm{M}^{n+}\right]\left[\mathrm{HS}^{\prime}\right]\right)$, and $\beta_{2}^{\prime}=\left[\mathrm{MHS}_{2}^{(n-2)+}\right] /\left(\left[\mathrm{M}^{n+}\right]\left[\mathrm{HS}^{\prime}\right]^{2}\right)$ (Eq. (8)).

$K_{1}^{\prime \prime}$ and $\beta_{2}^{\prime \prime}$ are conditional stability constants valid for seawater of the indicated salinity, both the metal and the bisulfide uncorrected for side-reactions: $K_{1}^{\prime \prime}=K_{1}^{\prime} / \alpha_{\mathrm{M}}^{\prime}=\left[\mathrm{MHS}^{(n-1)+}\right] /\left(\left[\mathrm{M}^{\prime}\right]\left[\mathrm{HS}^{\prime}\right]\right)$ and $\beta_{2}^{\prime \prime}=\beta_{2}^{\prime} / \alpha_{\mathrm{M}^{\prime}}=\left[\mathrm{MHS}_{2}^{(n-2)+}\right] /\left(\left[\mathrm{M}^{\prime}\right]\left[\mathrm{HS}^{\prime}\right]^{2}\right)$. 


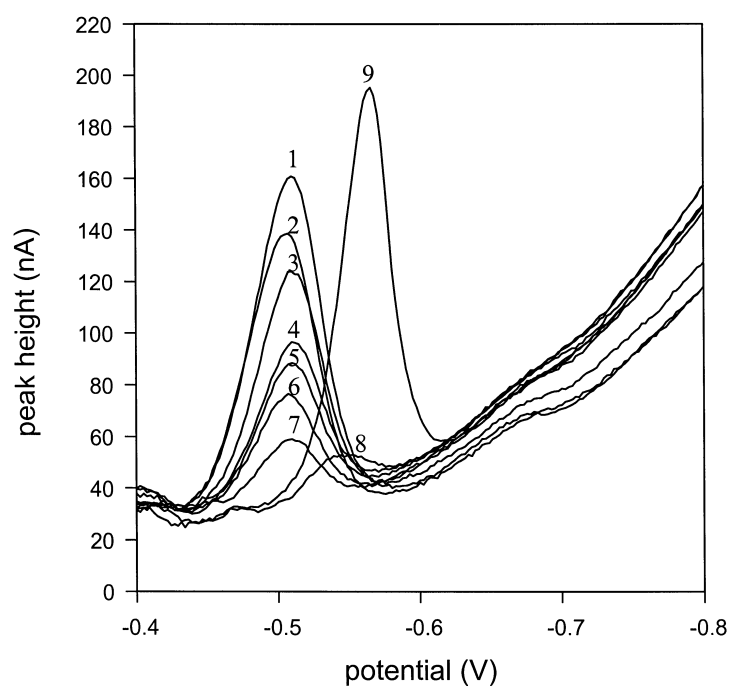

Fig. 3. The voltammetric response of the lead-oxine complex before and after addition of sulfide standards using $30 \mathrm{nM}$ of $\mathrm{Pb}$, $25 \mu \mathrm{M}$ of oxine and salinity of 35 ; (1) solution free of sulfide: after addition of (2) 50, (3) 100, (4) 150, (5) 200, (6) 250, (7) 300 , (8) 500, (9) $800 \mathrm{nM}$ sulfide, respectively. The free sulfide peak appears only at great supersaturation of the dissolved metal concentration possibly due to the adsorptive enhancement of the oxine species at the electrode surface causing interference with the free sulfide detection.

competing ligands for sulfide. However, the very high stability of the complexes with nioxime and DMG limited their use in this study, as unrealistically high levels of sulfide were required to compete effectively. Preliminary experiments showed that also cobalt and nickel formed electroactive complexes with oxine, and these had a lower stability than those with nioxime and DMG; the sensitivity was much lower than with DMG or nioxime, but it was sufficiently sensitive to determine the stability of the sulfide complexes as the metal concentrations in the experiments were higher than normally occurring in seawater.

The decrease in the metal peak heights ( $Q$-ratio, Eq. (35)) with increasing sulfide concentration is shown in Fig. 4. The stability constants were calculated by non-linear least squares regression of the $Q$-values to Eq. (35) assuming the presence of one metal-sulfide species of the type MHS and M(HS) or both simultaneously. Preliminary values for the constants were obtained by calculation of individual values using Eq. (37) for each data point followed by averaging. The values of the stability constants are shown in Table 3.

\section{Discussion}

The stability constants determined obtained in this work can be compared with those reported in the literature in Table 4. The literature data falls into two ca?tegories: experimentally determined stability constants, and stability constants estimated by the linear free energy technique. Dyrssen (1988) used dithizone as a model ligand to estimate the stability of metalsulfide complexes using stability constants for cadmium sulfide (Ste-Marie et al., 1964) and mercuric sulfide (Schwarzenbach and Widmer, 1963) as reference. The thus estimated values for other metalsulfide complexes depend therefore on the cadmium and mercury values and on whether dithizone is a good analogue for sulfide. The values of Zhang and Millero (1994) in Table 4 were obtained by titration of metals in seawater with sulfide and detection of free sulfide by CSV. They presented conditional stability constants uncorrected for side-reactions of the metal ions with the major anions in the seawater. We corrected their values for the inorganic side reactions (Ringbom and Still, 1972), using side-reaction coefficients, $\alpha_{\mathrm{M}}$ (Table 4) calculated using free major ion concentrations and stability constants for metal complexation valid for seawater (see Eq. (16)). The concentrations of the free major ions were calculated from the total ion concentrations and ion-pairing constants using an iterative ion-paring model. The values of Luther et al. (1996) were obtained by conventional, batch-wise, voltammetry, but they maximised the contribution of the diffusion current by not expressly using an adsorption step. The actual measurement may therefore have been quite short and sulfide losses due to the reaction with mercury would have been comparatively small; sulfide solutions were titrated with metals, so there would have been the possibility of sulfide suppression by waste mercury as well as dissolved mercuric ions during the experiment even though the individual measurements may have taken only a brief period of time. They used a combination of potential shifts and 

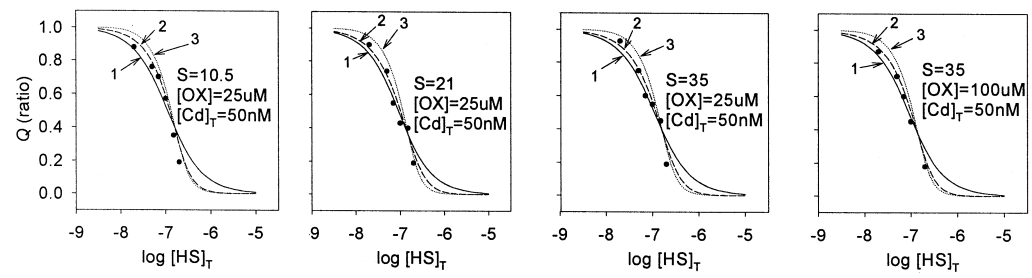

Cd
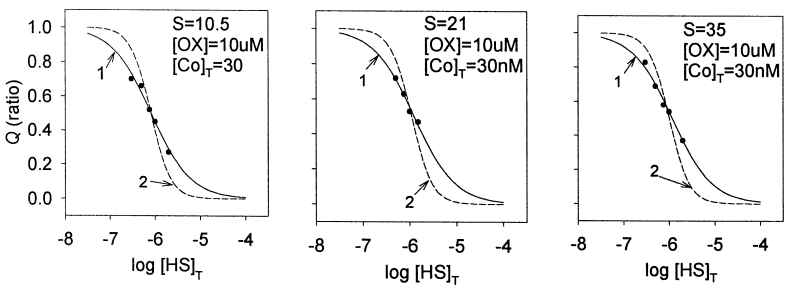

CoII
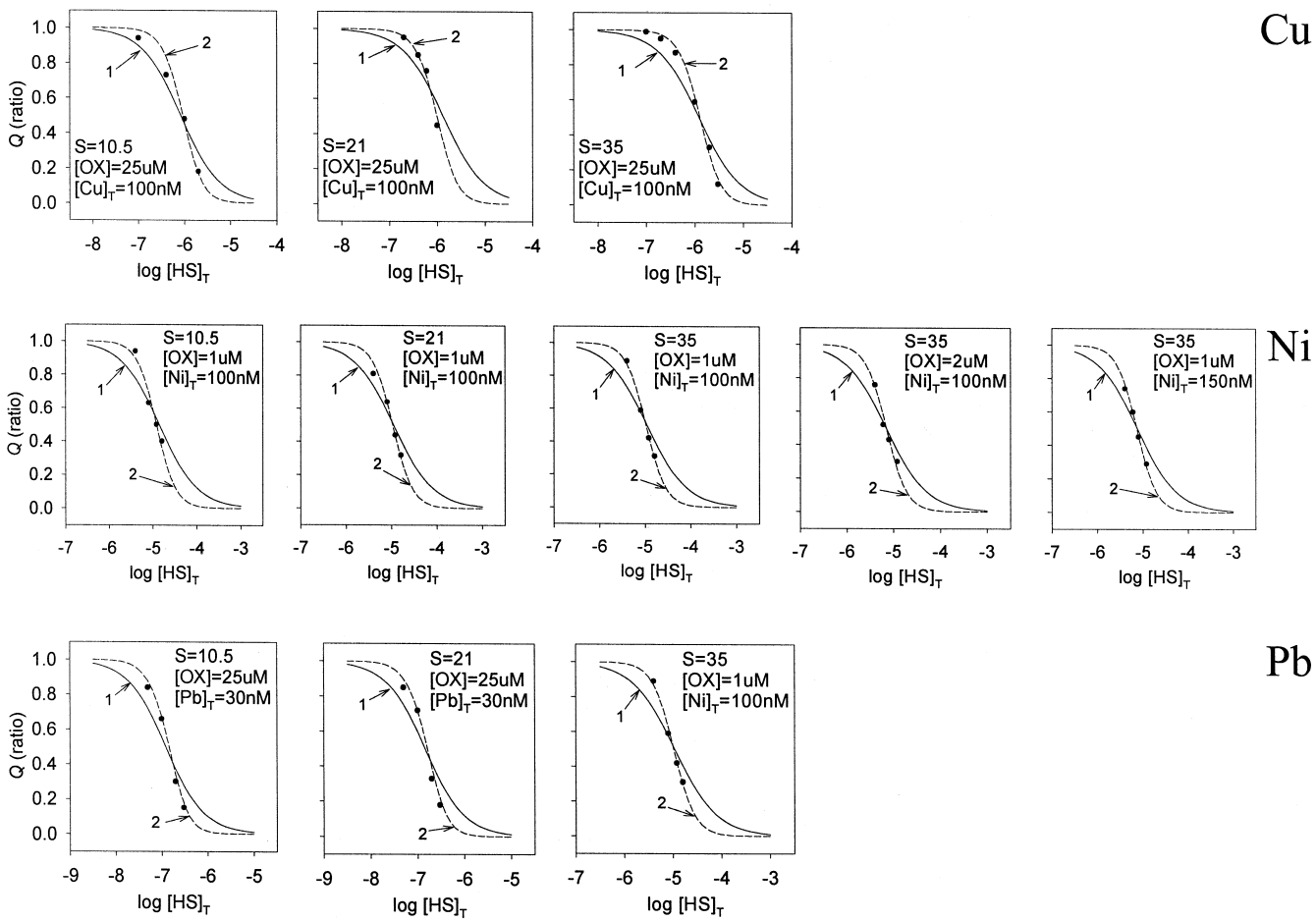

$\mathrm{Pb}$
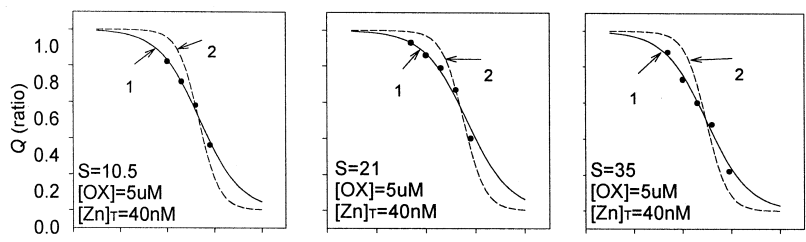

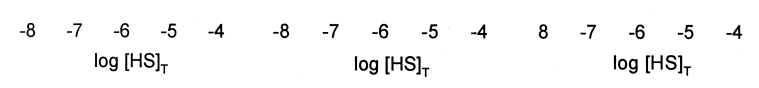


Table 3

Values for conditional stability constants of metal-sulfide determined by ligand competition and calculated by curve fitting

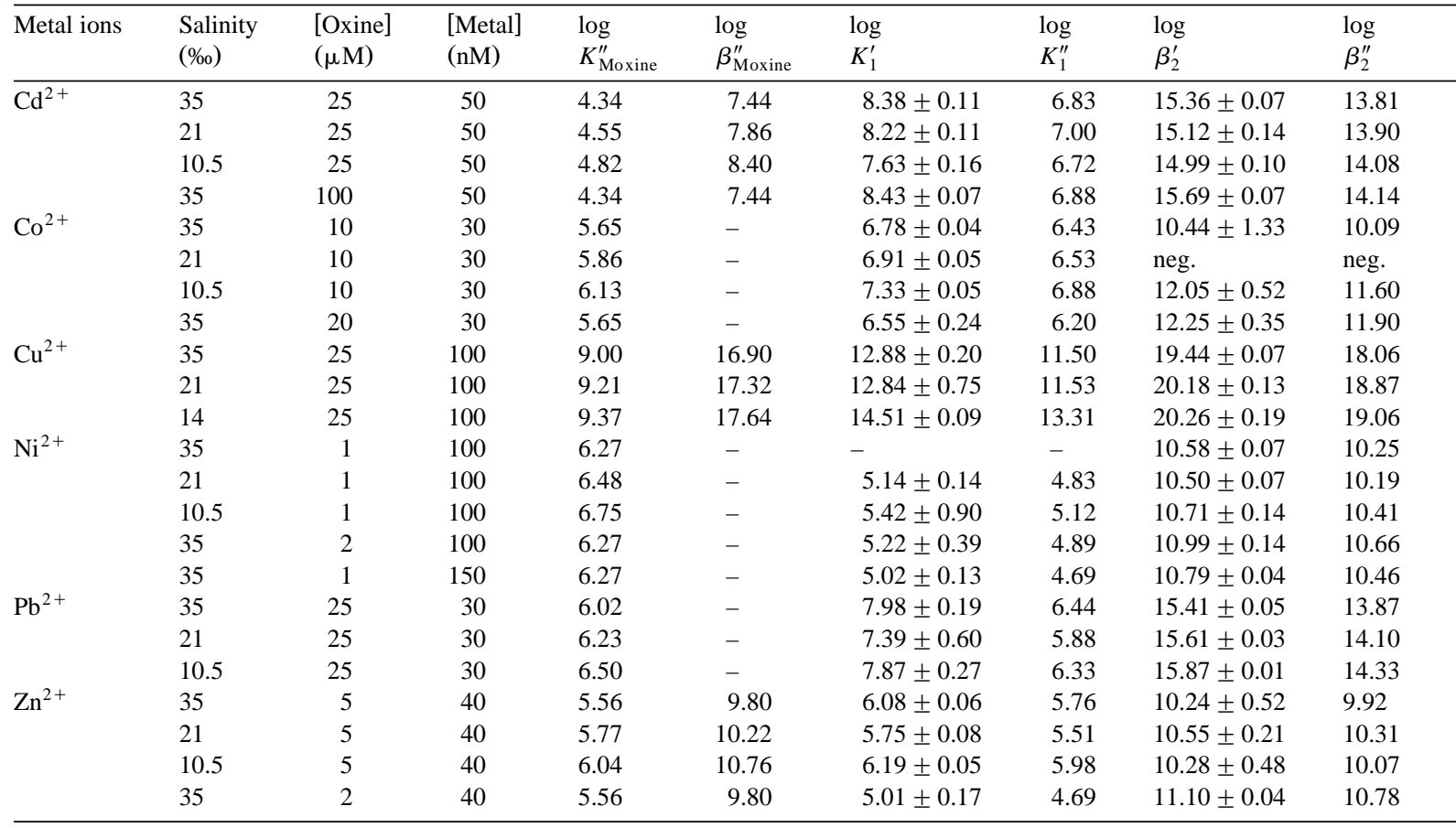

The conditional stability constants ( $K_{\text {Moxine }}^{\prime \prime}$ and $\beta_{\text {Moxine }}^{\prime \prime}$ ) for the metal-oxine complexes were calculated from constants from Stary et al. (1979) and are valid for the indicated salinities; e.g., $K_{\text {Moxine }}^{\prime \prime}=[\mathrm{M}-$ oxine $] /\left(\left[\mathrm{M}^{\prime}\right]\left[\right.\right.$ oxine $\left.\left.^{\prime}\right]\right)$ where $\left[\mathrm{M}^{\prime}\right]$ includes all metal species complexed with the major anions in seawater, and [oxine'] includes all species complexed with the major cations in seawater. The other constants as in Table 2.

reduction currents as a measure of complex stability, and used a mole ratio based entirely on currents in the case of copper and zinc.

The $\mathrm{pH}$ in our experiments was stabilised using $0.01 \mathrm{M}$ Tris buffer. This buffer forms complexes with metals too but the stability of these complexes is weak in seawater due to competition by the major cations; certainly in our previous measurements of complexation of copper, zinc, or iron we did not observe an effect (e.g., van den Berg, 1995). The constants reported here would be underestimated if complexation of Tris with the metals was significant compared to the complexation with bisulfide as the bisulfide would be competing against an additional, not-taken-into-account, complexing ligand.

\subsection{Comparison of the two techniques}

\subsubsection{Comparison of the free sulfide and the ligand competition data}

The stability constants for several metals could be determined using both methods (ligand competition and detection of free sulfide). The free sulfide data appeared to provide less resolution than the ligand competition data, and the experimental data were found to give a good fit only to one of the stability

Fig. 4. Titration of (cadmium, cobalt(II), copper, nickel, lead and zinc)-oxine complexes with sulfide. The lines represent the calculated variation in $Q$ using the fitted values for the constants. The constants were calculated by non-linear curve fitting to either (1) only one species (MHS), (2) two species (MHS and M(HS) $)_{2}$, and (3) only one species (M(HS) $)_{2}$. 
Table 4

Comparison of conditional stability constants (corrected for side-reactions of the metal ion in seawater as in Table 2Table 3 ) of metal bisulfide species in seawater of $\mathrm{pH} 8$ and at $25^{\circ} \mathrm{C}$, with literature data

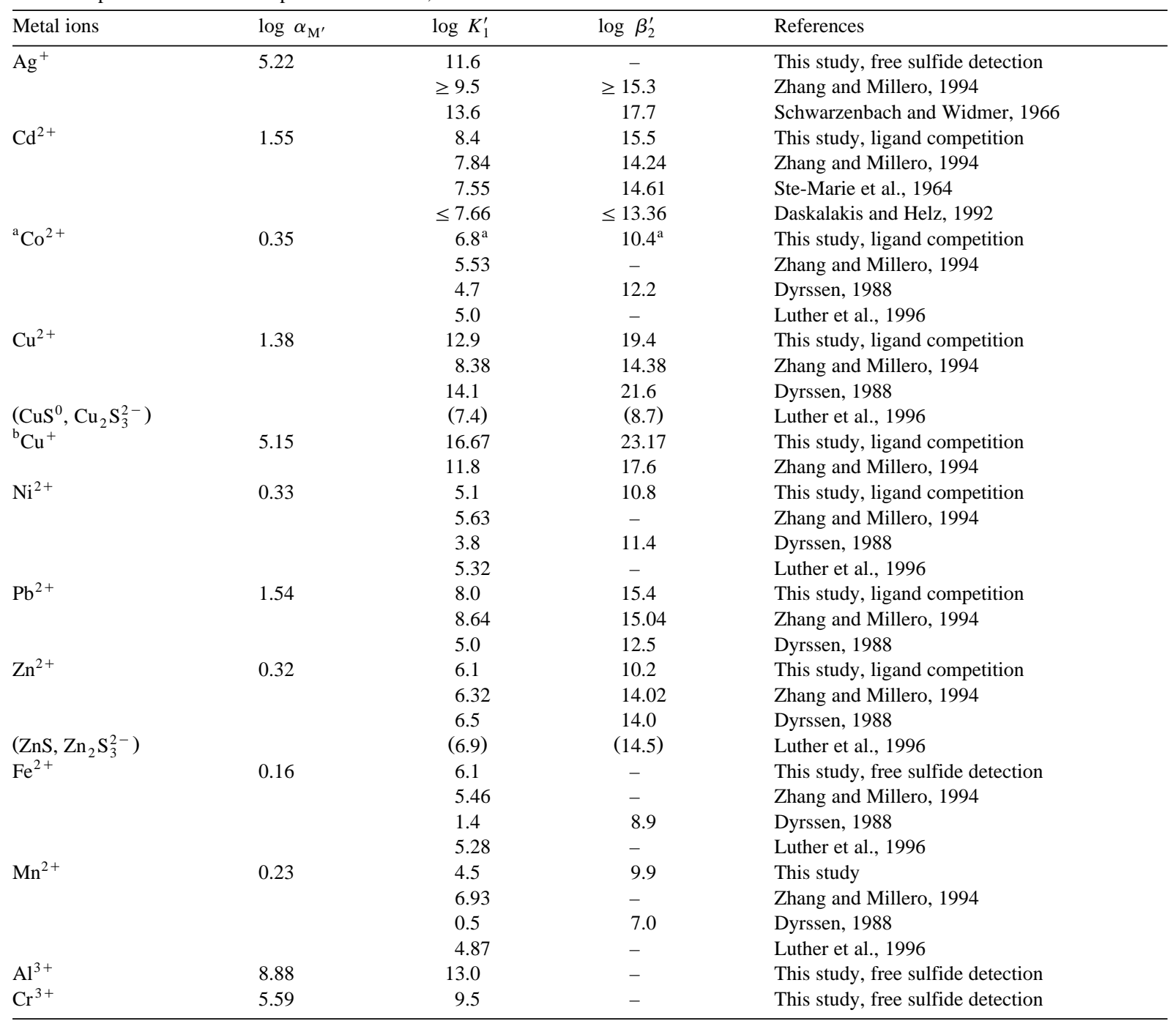

${ }^{\mathrm{a}}$ Determined at $\mathrm{pH}=9.0$.

${ }^{\mathrm{b}}$ Calculated from the same data as for $\mathrm{Cu}^{2+}$.

Constants for metal-sulfide species $\left(K_{\mathrm{M}^{\prime} \mathrm{S}}^{\prime}\right)$ (where indicated) were converted to the conditional stability constants valid for seawater $\left(K_{1}^{\prime}=K_{\mathrm{Mn}+\mathrm{HS}^{\prime}}^{\prime}\right)$ used here: $K_{1}^{\prime}=K_{\mathrm{M}^{\prime} \mathrm{S}}^{\prime} / \alpha_{\mathrm{S}}$ where $\alpha_{\mathrm{S}}$ was calculated from $\left[\mathrm{H}^{+}\right] / K_{1 \mathrm{a}}: \alpha_{\mathrm{S}}=10^{5.6}$ for $\mathrm{pH} 8$ seawater. The data of Luther et al. (1996) for $\mathrm{Cu}$ and $\mathrm{Zn}$ are bracketed because they were calculated from constants which were specifically for metal-sulfide (not bisulfide) species.

constants (either $K_{\mathrm{MHS}}^{\prime}$ or $\beta_{\mathrm{M}(\mathrm{HS})_{2}}^{\prime}$ ). Comparison of the results (Table 5) shows close agreement once the values for both $K_{\mathrm{MHS}}^{\prime}$ and $\beta_{\mathrm{M}(\mathrm{HS})_{2}}^{\prime}$ are taken into account. For instance, a value of 9.1 was obtained for $\log K_{\mathrm{CdHS}}^{\prime}$ using the free sulfide method; these data indicated insignificant formation of $\mathrm{Cd}(\mathrm{HS})_{2}^{0}$ causing the calculation of a value for $\beta_{\mathrm{Cd}(\mathrm{HS})_{2}}^{\prime}$ to be inaccurate. A value of 8.4 was obtained $\log K_{\mathrm{CdHS}}^{\prime}$ 
Table 5

Comparison of conditional stability constants determined by ligand competition and by measurement of the free sulfide concentration

\begin{tabular}{lllll}
\hline Metal ions & \multicolumn{2}{l}{ Ligand competition } & \multicolumn{2}{l}{ Free sulfide } \\
\cline { 2 - 5 } & $\log K_{1}^{\prime}$ & $\log \beta_{2}^{\prime}$ & $\log K_{1}^{\prime}$ & $\log \beta_{2}^{\prime}$ \\
\hline $\mathrm{Cd}^{2+}$ & 8.4 & 15.5 & 9.1 & - \\
$\mathrm{Co}^{2+}$ & 6.8 & 10.4 & 6.4 & 9.8 \\
$\mathrm{~Pb}^{2+}$ & 8.0 & 15.4 & - & 16.4 \\
$\mathrm{Zn}^{2+}$ & 6.1 & 10.2 & 6.2 & - \\
\hline
\end{tabular}

using the ligand competition method associated with a value of 15.5 for $\beta_{\mathrm{Cd}(\mathrm{HS})_{2}}^{\prime}$. A value for $\beta_{\mathrm{Cd}(\mathrm{HS})_{2}}^{\prime}$ could not be calculated using the free sulfide data so the free sulfide- $K_{\mathrm{CdHS}}^{\prime}$ value takes the contribution of the second species into account. It was attempted to calculate (using the free sulfide data) a value for $K_{\mathrm{CdHS}}^{\prime}$ using the value for $\beta_{\mathrm{Cd}(\mathrm{HS})_{2}}^{\prime}$ from the ligand competition method, but this gave a meaningless value for $K_{\mathrm{CdHS}}^{\prime}$.

The value for $\log K_{\mathrm{CoHS}}^{\prime}$ (6.8) from the ligand competition data was slightly larger than that obtained using the free sulfide data, but the difference was offset by a smaller value for $\beta_{\mathrm{Co}(\mathrm{HS})_{2}}^{\prime}$ (Table 5).

The accuracy of the results obtained by the ligand competition method depends on the accuracy of the stability of the metal-oxine complexes. Fortunately a good set of stability constants is available for metal-oxine interactions (Stary et al., 1979). Furthermore it was assumed that any interaction of the metal bisulfide complexes with oxine was negligible (i.e., no mixed metal-sulfide-oxine complexes were formed). Such interaction between a natural organic ligand with iron(II) sulfide complexes has been hypothesized to explain the slow kinetics for iron(II) sulfide complexes in marine waters (Luther and Ferdelman, 1993). A similar interaction between the metal-sulfide complex and oxine would lower the apparent values of the stability constants of the metal-sulfide complexes. The good agreement of the data obtained using the two methods suggests that there is no evidence for significant formation such mixed complexes.

A possible advantage of the ligand competition method over the free sulfide method is the elimination of precipitation of metal-sulfides. The solubility of the metal-sulfides may be transgressed when either the sulfide or the metal concentration is in- creased during the titrations, leading to precipitation of the solid phase of the metal-sulfide, although this was not observed in this work or previously (Zhang and Millero, 1994). The free metal ion concentrations were kept low during the experiments due to the presence of the competing ligand, oxine, thus minimizing the potential formation of poorly soluble sulfide species during the experiments.

A potential drawback of the method employing detection of free sulfide to determine the complex stabilities is that dissociation could occur of the complexes in the diffusion layer surrounding the electrode; this would render these complexes labile and they would either not be detected at all or this would lead to underestimation of the stability constant. Complex dissociation could occur if the concentration of free bisulfide would be greatly reduced in the diffusion layer. This was minimised by not lowering the free bisulfide concentration below $50 \%$ of the total concentration. Comparison of the stability constants determined by both methods in Table 5 shows no evidence for an underestimation of the complex stabilities using the sulfide detection method; there was therefore no significant contribution of sulfide dissociated from metal complexes to the detected free sulfide concentrations. The situation could be different when a conventional, batch, voltammetric cell is used where free mercury is present which tends to remove free sulfide from solution and which may compete with the added metal ions. This problem did not occur in our measurements because of the use of a flow-cell for the measurements. On the whole, and in spite of large differences between several individual constants, comparison of the constants found by this work with those obtained using the batch-voltammetric method reported in the literature (Table 4 ) reveals no system- 
atic underestimation of the complex stabilities by the batch method either.

\subsection{Sulfide complexes with copper and silver}

The stability constant $\left(\log K_{1}^{\prime}\right)$ obtained for copper (12.9) is smaller than that (14.1) estimated by Dyrssen, but it is much greater than that (8.4) found by Zhang and Millero (1994). Luther et al. (1996) found no evidence for copper complexation by bisulfide and explained their data using a $\mathrm{Cu}(\mathrm{II}) \mathrm{S}$ species instead. Their work suggested 1:1 complexes of copper at the beginning the titrations, but the ratio changed at higher sulfide concentrations; our data indicate that the copper speciation is dominated by the $1: 1 \mathrm{CuHS}^{+}$species but it is possible that $\mathrm{Cu}(\mathrm{HS})_{2}^{0}$ species are formed at higher bisulfide concentrations. Disregarding for the moment the different opinions regarding copper complexation by sulfide or bisulfide it is still possible to compare the complex stabilities with sulfide generally. The conditional stability constant from the data of Luther et al. (1996) $\left(\log K_{\left(\mathrm{Cu}^{2+}\right)\left(\mathrm{HS}^{\prime}\right)}^{\prime}\right)$ for copper complexation (as $\mathrm{Cu}(\mathrm{II}) \mathrm{S}$ ) by sulfide (7.36) is slightly less than that of Zhang and Millero (1994), and much less than that found here (as $\mathrm{CuHS}^{+}$) by ligand competition.

Our value for silver (11.6) is greater than that ( $>9.5$ ) found by Zhang and Millero (1994) which was below the limit of detection in their procedure; our value is smaller than that (13.6) obtained from sulfide solubility (Schwarzenbach and Widmer, 1966). Our value for the copper sulfide constant is high compared to the complex stabilities of the other divalent metal ions, and similar to that for silver sulfide where silver occurs as $\operatorname{Ag}(\mathrm{I})$. Recent work (Leal and van den Berg, 1997) has indicated that copper(I) complexes with thiols like glutathione are very stable in seawater with a value for $\log K_{\mathrm{CuGS}}^{\prime \prime}$ of 10.6 (equivalent to a value for $\log K_{\mathrm{Cu}^{2+} \mathrm{GS}}^{\prime}$ of 12.2 ), similar to that for copper with sulfide. ( $K_{\mathrm{CuGS}}^{\prime \prime}$ is valid for copper generally, regardless of the oxidation state, whereas $K_{\mathrm{Cu}^{2+} \mathrm{GS}}^{\prime}$ is valid for $\mathrm{Cu}^{2+}$ and $\mathrm{GS}^{\prime}$ ). In view of the similarity of the ligands (the sulfide group is involved in both complexes), and the similarity with silver(I), it may be hypothesized that the copper occurs as copper(I) in the sulfide complex. Zhang and Millero (1994) have attempted to determine a value for the copper(I) complex sepa- rately and found a value for $K_{\mathrm{Cu}(\mathrm{I}) \mathrm{HS}}^{\prime}$ of 11.8 . This is equivalent to a value of 6.8 for $\log K_{\mathrm{CuHS}}^{\prime \prime}$ (calculated from their constant by removing the correction for side-reactions of $\mathrm{Cu}^{+}$by division of $K_{\mathrm{CuHS}}^{\prime \prime}$ by $\left.\alpha_{\mathrm{Cu}(\mathrm{I})^{\prime}}\right)$ which is almost the same as the value (7.0) for $\log K_{\mathrm{CuHs}}^{\prime \prime}$ which is obtained when the correction for side-reactions of $\mathrm{Cu}^{2+}$ is removed from their constant for $\mathrm{Cu}^{2+}$ complexation $\left(\log K_{\mathrm{Cu}(\mathrm{II}) \mathrm{HS}}^{\prime}=\right.$ 8.38) (Table 4). A possible explanation for the apparent similarity is that the redox reaction of $\mathrm{Cu}(\mathrm{I}) / \mathrm{Cu}$ (II) is electrochemically reversible; it is therefore not possible to retain the original redox state of free copper in the diffusion layer of the electrode when a potential is applied or when the potential is scanned. Zhang and Millero (1994) used a deposition potential of $-0.1 \mathrm{~V}$ where free copper would have occurred as copper(II) in the diffusion layer regardless of the original oxidation state of dissolved copper in the bulk solution. It is therefore likely that they determined the stability of the copper(II) sulfide complex twice. Luther et al. (1996) scanned without a deliberate preconcentration step, but they would nevertheless have oxidized $\mathrm{Cu}(\mathrm{I})$ to $\mathrm{Cu}$ (II) during the beginning of the scan and back to $\mathrm{Cu}(\mathrm{I})$ during the remainder of the scan, so they too have suffered from changes in the speciation during the measurement of which the net effect is not known. The previous work therefore does not conclusively show whether copper in seawater is complexed by sulfide as copper(I) or as copper(II).

Using ligand competition between oxine and sulfide we used a slightly more negative deposition potential than that of Zhang and Millero (1994) of $-0.2 \mathrm{~V}$ which would tend to cause some reduction of free copper(II) to copper(I) as the reduction potential for free copper is around $-0.17 \mathrm{~V}$ in seawater. However, experiments using a specific copper(I) binding ligand (glutathione) have shown that the effect of the deposition potential in the ligand competition method is very slight or insignificant (Leal and van den Berg, 1997) presumably as most copper is stabilised as copper(II)-oxine complexes leaving only a small fraction $(<0.1 \%)$ as free uncomplexed copper. It is therefore likely that CSV measurements using the ligand competition method do not significantly affect the redox state of copper. Assuming that the sulfide complex detected by us is indeed with copper(I) (in view of the high complex stability 
greater than that with silver, and the similarity with glutathione) then this species would be predominant and the presence of free sulfide would tend to cause reduction of dissolved copper(II) to copper(I) in seawater in the absence of applied electrode potentials.

5.3. Sulfide complexes with divalent metals: $\mathrm{Cd}$, Co, $\mathrm{Fe}, \mathrm{Mn}, \mathrm{Ni}, \mathrm{Pb}$, and $\mathrm{Zn}$

\subsubsection{Comparison with literature data}

The values for $\log K_{\mathrm{MHS}}^{\prime}$ for cadmium and iron(II) are about 0.5 units greater, and those for nickel, lead, and zinc 0.2-0.5 units smaller, than those obtained by Zhang and Millero (1994). The relatively small differences are surprising as the conventional, batch voltammetric method suffers from a continuous and rapid decrease in the CSV response for free sulfide due its reaction with waste mercury (Al-Farawati and van den Berg, 1997). Zhang and Millero (1994) measured the free sulfide concentration $60 \mathrm{~s}$ after each sulfide addition, and continued their sulfide additions to high concentrations (micromolar). Possibly the effect of the sulfide removal was minor in these conditions, or possibly the data treatment was relatively insensitive to the continuous removal of a fraction of the free sulfide.

The value for the constant for cobalt (6.8) is greater than that (5.5) found by Zhang and Millero (1994) and that (4.7) found by Luther et al. (1996) and also than that (4.7) estimated by Dyrssen (1988). The constant for cobalt was determined at a slightly higher $\mathrm{pH}$ ( 9 instead of 8) but this does not affect the value of the conditional stability constant as this is based on bisulfide which is predominant over a $\mathrm{pH}$ range of 6.7 to 13.6. The relatively close agreement between our result for cobalt using both methods (free sulfide and ligand competition, both using the flow-cell) is encouraging for the new data, and indicates that there is a problem with the previous data. It is possible that different, higher order, species (perhaps with weaker complex stability) are formed at higher cobalt and sulfide concentrations than used here, which could explain the difference with the literature data.

The value for $\mathrm{Mn}$ (4.5) is much less than that (6.9) found by Zhang and Millero (1994), but similar to that (4.6) of Luther et al. (1996). It is not clear whether changes in the redox state during deposition have contributed to the differences.

Instead of a stability constant for zinc species of the form $\left[\mathrm{M}(\mathrm{HS})_{m}\right]^{(n-m)+}$ Luther et al. (1996) reported a constant (converted here to $\log K_{\left(\mathrm{Zn}^{2+} \mathrm{HS}\right)}^{\prime}=$ 6.9) for a species of the type $\mathrm{ZnS}$. Disregarding the disagreement on whether zinc is complexed by $\mathrm{S}^{2-}$ or by $\mathrm{HS}^{-}$the conditional constants found previously for zinc complexation by sulfide generally are relatively similar to that found by us.

\subsection{Modeling of the sulfide speciation in seawater}

Oxygenated seawater contains sulfide at levels of 0.1 to $2 \mathrm{nM}$ (Cutter and Krahforst, 1988; Luther and Tsamakis, 1989; Radford-Knoery and Cutter, 1994). This sulfide concentration is of the same magnitude as that of copper, and similar to, or greater than, that of other metals for which stability constants were determined in this study. Because of the very great stability of the copper sulfide complexes it is likely that copper controls the speciation of sulfide and vice versa sulfide controls the speciation of copper. The sulfide speciation in the presence of several trace metals is calculated here in a manner similar to that done before (Dyrssen, 1988; Elliott, 1988; Dyrssen and Wedborg, 1989; Zhang and Millero, 1994). The calculation was carried out using realistic total metal and sulfide concentrations, and mass balance equations for metals and bisulfide.

The speciation of sulfide with copper was calculated in the presence and absence of organic complexing ligands, and without making assumptions regarding complexation of copper as copper(I) or (II) by using the conditional stability constant $\left(K_{\mathrm{CuHS}}^{\prime \prime}\right)$. A stability constant and organic ligand concentration was selected from copper complexing ligands occurring in seawater (van den Berg, 1984a). Concentrations of organic ligands and their conditional stability constants for copper complexation in waters originating from the Atlantic Ocean have been determined by CSV using catechol as competitive ligand (van den Berg, 1984a). Two ligands were observed at concentrations of 11 and $33 \mathrm{nM}$ with conditional stability constants (log values) of 12.2 and 10.2, respectively.

The concentrations of cadmium, lead, nickel, cobalt and zinc were taken from Bruland (1983), of 
aluminum and silver from Broecker and Peng (1982) and for chromium(III) from van den Berg et al. (1994). Sulfide concentrations of 0.5 and $2 \mathrm{nM}$, and copper concentrations of 1,5 and $10 \mathrm{nM}$, were used in the presence and absence of organic ligands.

\subsubsection{At a total sulfide concentration of $0.5 \mathrm{nM}$}

Table 6 shows the speciation of sulfide at several copper concentrations and in the absence and presence of organic ligands. In the absence of the organic copper binding ligand and at a concentration of 0.5 $\mathrm{nM}$ sulfide the sulfide occurs predominantly complexed with copper, amounting to more than $99 \%$ of all sulfide at all copper concentrations. This finding is in general agreement with the previous work although it was attributed to a different copper sulfide species (Dyrssen, 1988; Elliott, 1988). In the presence of organic ligands some of the copper is organic-bound; this releases a large fraction of the sulfide as free bisulfide ( $72 \%$ at a copper concentration of $1 \mathrm{nM}$ ), and copper monobisulfide amounts to $28 \%$ of the sulfide. This is interesting because free sulfide is known to be oxidized by iodate (Zhang and Whitfield, 1986) and oxygen (Millero, 1991) in seawater whilst one could expect the copper sulfide species to be stabilised. Free sulfide is thought to amount to $\sim 20 \%$ of total sulfide in seawater originating from the western North Atlantic and is readily purged with inert gas at natural $\mathrm{pH}$ (Radford-Knoery and Cutter, 1994). This may confirm the importance of the indirect influence of organic ligands on the speciation of sulfide. At copper concentrations of 5 and $10 \mathrm{nM}$, the copper monobisulfide dominates the sulfide speciation.

\subsubsection{At a total sulfide concentration of $2 \mathrm{nM}$}

At a copper concentration of $1 \mathrm{nM}$ and in the absence of organic ligand, half of the sulfide occurs as free bisulfide whereas the rest is copper monobisulfide. At higher copper concentrations the sulfide speciation is dominated by copper monobisulfide. In the presence of organic complexing ligands the calculated free sulfide concentration is increased to 79 , 31 and $9 \%$ at copper concentrations of 1,5 and 10

Table 6

Percentage speciation of sulfide species in the presence and absence of an organic ligand at various concentrations of copper

\begin{tabular}{|c|c|c|c|c|c|c|}
\hline \multirow{2}{*}{$\frac{[\mathrm{HS}]_{\mathrm{T}}=0.5 \mathrm{nM}}{[\mathrm{Cu}]_{\mathrm{T}}}$} & \multicolumn{3}{|c|}{ In the absence of organic ligand } & \multicolumn{3}{|c|}{ In the of presence organic ligand } \\
\hline & $1 \mathrm{nM}$ & $5 \mathrm{nM}$ & $10 \mathrm{nM}$ & $1 \mathrm{nM}$ & $5 \mathrm{nM}$ & $10 \mathrm{nM}$ \\
\hline$\overline{\left[\mathrm{HS}^{\prime}\right]}$ & 0.62 & 0.07 & 0.03 & 71.77 & 23.90 & 5.98 \\
\hline $\mathrm{CuHS}^{+}$ & 99.38 & 99.93 & 99.97 & 28.08 & 76.01 & 93.99 \\
\hline $\mathrm{Cu}(\mathrm{HS})_{2}^{0}$ & 0 & 0 & 0 & 0.07 & 0.06 & 0.02 \\
\hline $\mathrm{PbHS}^{+}$ & 0 & 0 & 0 & 0.03 & 0.01 & 0 \\
\hline $\mathrm{NiHS}^{+}$ & 0 & 0 & 0 & 0.01 & 0 & 0 \\
\hline $\mathrm{AlHS}^{2+}$ & 0 & 0 & 0 & 0.03 & 0 & 0 \\
\hline AgHS & 0 & 0 & 0 & 0.01 & 0 & 0 \\
\hline Others & 0 & 0 & 0 & 0 & 0.02 & 0.01 \\
\hline Total & 100 & 100 & 100 & 100 & 100 & 100 \\
\hline $\begin{array}{l}{[\mathrm{HS}]_{\mathrm{T}}=2 \mathrm{nM}} \\
{\left[\mathrm{HS}^{\prime}\right]}\end{array}$ & 49.9 & 0.1 & 0.04 & 79.1 & 31.1 & 8.99 \\
\hline $\mathrm{CuHS}^{+}$ & 49.7 & 99.9 & 99.96 & 20.6 & 68.6 & 90.9 \\
\hline $\mathrm{Cu}(\mathrm{HS})_{2}^{0}$ & 0.3 & 0 & 0 & 0.2 & 0.3 & 0.1 \\
\hline $\mathrm{PbHS}^{+}$ & 0.02 & 0 & 0 & 0.04 & 0.01 & 0 \\
\hline $\mathrm{NiHS}^{+}$ & 0.01 & 0 & 0 & 0.01 & 0 & 0 \\
\hline $\mathrm{AlHS}^{2+}$ & 0.02 & 0 & 0 & 0.03 & 0.01 & 0 \\
\hline $\mathrm{AgHS}$ & 0 & 0 & 0 & 0.01 & 0 & 0 \\
\hline Others & 0.01 & 0.01 & 0 & 0 & 0.03 & 0.01 \\
\hline Total & 100 & 100 & 100 & 100 & 100 & 100 \\
\hline
\end{tabular}

The sulfide concentration is 0.5 or $2 \mathrm{nM}$, and the trace metal concentrations are from Broecker and Peng (1982) and Bruland (1983); conditional stability constants and organic ligand concentrations are from van den Berg (1984a). 
$\mathrm{nM}$, respectively, and the copper monobisulfide concentration is decreased to 21,69 and $91 \%$, respectively.

These calculations show that the ratio of total copper and total bisulfide determines sulfide speciation in the absence of organic complexation of copper. At a $\mathrm{S}: \mathrm{Cu}$ ratio of two sulfide occurs as copper monobisulfide, and half of the sulfide occurs as free bisulfide. In the presence of copper complexing organic ligands some of the sulfide is released and occurs mainly as free bisulfide due to competitive complexation of the copper by the organic ligands.

\subsection{Copper speciation}

Due to the great stability of the sulfide copper complexes it is likely that the sulfide is a major ligand for copper even at low sulfide concentrations. Disregarding sulfide the inorganic speciation of copper in seawater is dominated by carbonate complexation (Turner et al., 1981; van den Berg, 1984b). Organic complexing ligands are known to bind most copper in seawater, and are present in excess (Hirose et al., 1982; Mills et al., 1982; van den Berg, 1984a; Coale and Bruland, 1988; Zhou and Wangersky, 1989). The speciation of copper over organic and sulfide complexes is recalculated here as function of the sulfide concentration at a total copper concentration of $1.2 \mathrm{nM}$ using the new constants for the copper sulfide species, and is shown in Fig. 5. In the absence of organic complexing ligands the copper monobisulfide is the major copper species at total sulfide concentrations of $0.5-1000 \mathrm{nM}$. This species can be expected to play a major role in determining the geochemistry of copper in oxic-anoxic boundaries in the marine environment. At total sulfide concentrations $>1000 \mathrm{nM}$ copper dibisulfide is the main species.

In the presence of organic complexation the copper-organic species are dominant at sulfide $<1 \mathrm{nM}$, but at higher levels of sulfide, first copper monobisulfide, and then copper dibisulfide complexes constitute the major species.

The dominant influence of copper over the sulfide speciation does not explain the apparent stabilisation of sulfide in seawater as copper sulfide complexes
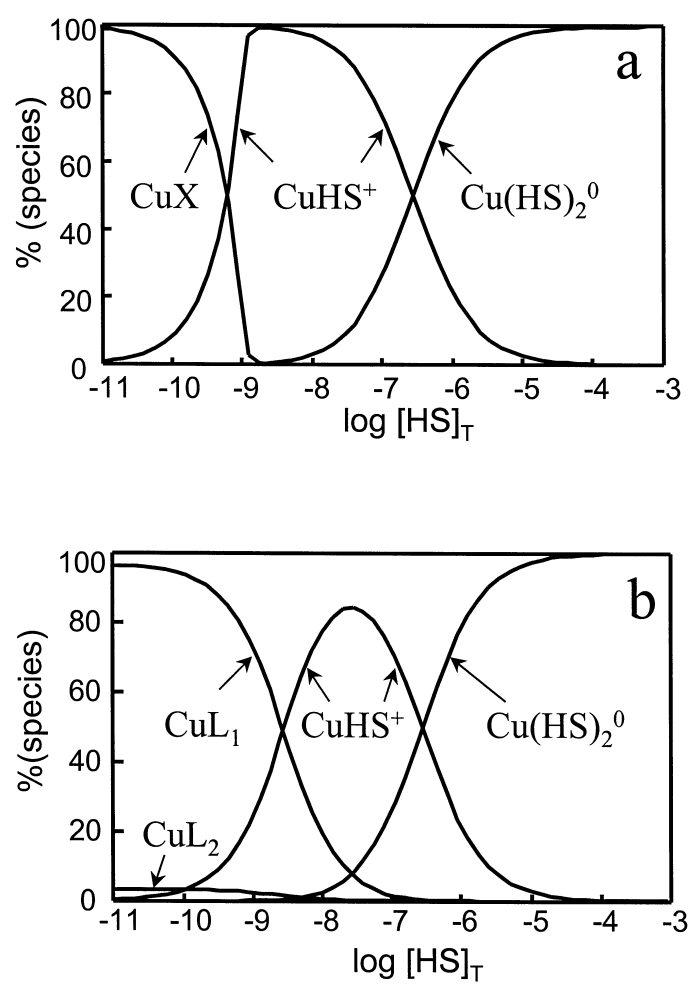

Fig. 5. Copper speciation as a function of $\log [\mathrm{HS}]_{\mathrm{T}}$ : in the absence (a) and presence (b) of organic ligands. $[\mathrm{Cu}]_{\mathrm{T}}=1.2 \mathrm{nM}$; the concentration of organic ligand $\mathrm{L}_{1}=11 \mathrm{nM}$ and $\log K_{\mathrm{CuL}_{1}}^{\prime}=$ 12.2; the concentration of organic ligand $\mathrm{L}_{2}=33 \mathrm{nM}$ and $\log$ $K_{\mathrm{CuL}_{2}}^{\prime}=10.2$.

are thought to become oxidised more quickly than free sulfide (Vazquez et al., 1989). It is therefore likely that the presence of sulfide in seawater is the result of a steady state of on-going processes of production (such as in flocs of bacteria and other microorganisms) and oxidation by dissolved oxygen.

\section{Conclusions}

Good agreement for stability constants for metal-sulfide complexation are obtained when determined using a flow cell combined with either ligand competition or detection of the free sulfide concentration. Comparative measurements shown that the conditional stability constants $\left(\log K_{1}^{\prime}\right)$ of cobalt(II) and zinc sulfide species determined by both methods show a close agreement. The stability constants for 
sulfide complexes with copper in seawater determined with the flow cell are much greater than those determined previously using a conventional cell. The differences are less for other metals. The data suggest that copper in seawater is complexed strongly by sulfide, but it is not clear whether it is complexed as $\mathrm{Cu}(\mathrm{I})$ or as $\mathrm{Cu}(\mathrm{II})$. Using non-linear, least-squares, curve fitting it was demonstrated that the predominant sulfide species with silver, iron(II), aluminum and chromium(III) in seawater are monobisulfide species.

Calculation of the sulfide speciation in seawater typical for oceanic waters ( $1 \mathrm{nM}$ copper, and $0.5 \mathrm{nM}$ sulfide) but free of organic ligands indicates that the speciation of sulfide is dominated by complexation of copper and occurs mainly as copper monobisulfide. In the presence of organic ligands, about two third of the total sulfide is present as free sulfide and the rest as copper monobisulfide. However, the sulfide speciation depends greatly on the ratio of copper to sulfide, and on the stability and concentration of organic copper complexing ligands. Conversely, the inorganic speciation of copper is strongly affected by sulfide ions when the sulfide concentration is greater than or equal to the copper concentration.

\section{Acknowledgements}

The research of R.A. was supported by a Scholarship of the Saudi Arabian Government. We much appreciate the detailed suggestions to the manuscript by the referees and the associate editor (G. Luther).

\section{References}

Achterberg, E.P., van den Berg, C.M.G., Boussemart, M., Davison, W., 1997. Speciation and cycling of trace metals in Esthwaite water, a productive English Lake with seasonal deep-water anoxia. Geochim. Cosmochim. Acta, submitted.

Al-Farawati, R., van den Berg, C.M.G., 1997. The determination of sulfide in seawater by flow-analysis with voltammetric detection. Mar. Chem, in press.

Balistrieri, L.S., Murray, J.W., Paul, B., 1992. The biogeochemical cycling of trace metals in the water column of Lake Sammamish, Washington: response to seasonally anoxic conditions. Limnol. Oceanogr. 37 (2), 529-548.
Balistrieri, L.S., Murray, J.W., Paul, B., 1994. The biogeochemical cycling of trace elements in a biogenic meromictic lake. Geochim. Cosmochim. Acta 58, 3993-4008.

Broecker, W.S., Peng, T.H. (Eds.), 1982. Tracers in the sea. Lamont-Doherty Geological Observatory.

Bruland, K.W., 1983. Trace elements in seawater. In: Riley, J.P., Chester, R. (Eds.), Chemical Oceanography, 2nd edn. Academic Press, pp. 157-200.

Campos, M.L.A.M., van den Berg, C.M.G., 1994. Determination of copper complexation in seawater by cathodic stripping voltammetry and ligand competition with salicylaldoxime. Anal. Chim. Acta 284, 481-496.

Ciglenecki, I., Cosovic, B., 1996. Electrochemical study of sulfur species in seawater and marine phytoplankton cultures. Mar. Chem. 52, 87-97.

Coale, K.H., Bruland, K.W., 1988. Copper complexation in the Northeast Pacific. Limnol. Oceanogr. 33 (5), 1084-1101.

Colombo, C., van den Berg, C.M.G., 1997. Simultaneous determination of several trace metals in seawater using cathodic stripping voltammetry with mixed ligands. Anal. Chim. Acta 337 (1), 29-40.

Colombo, C., van den Berg, C.M.G., Daniel, A., 1997. A flow cell for on-line monitoring of metals in natural waters by voltammetry with a mercury drop electrode. Anal. Chim. Acta 346, 101-111.

Cutter, G.A., Krahforst, C.F., 1988. Sulfide in surface waters of the Western Atlantic Ocean. Geophys. Res. Lett. 15, 1393 1396.

Daskalakis, K.D., Helz, G.R., 1992. Solubility of CdS (greenockite) in sulfidic waters at $25^{\circ} \mathrm{C}$. Environ. Sci. Technol. 26, 2462-2468.

Davison, W., 1977b. The polarographic measurement of $\mathrm{O}_{2}$, $\mathrm{Fe}^{2+}, \mathrm{Mn}^{2+}$ and $\mathrm{S}^{2-}$ in hypolimnetic water. Limnol. Oceanogr. 22, 746-753.

Davison, W., Gabbutt, C.D., 1979. Polarographic methods for measuring uncomplexed sulfide ions in natural waters. J. Electroanal. Chem. 99, 311-320.

Davison, W., Heaney, S.I., 1978. Ferrous iron-sulfide interactions in anoxic hypolimnetic waters. Limnol. Oceanogr. 23 (6), 1194-1200.

Dickson, A.G., Whitfield, M., 1981. An ion-association model for estimating acidity constants (at $25^{\circ} \mathrm{C}$ and 1 atm total pressure) in electrolyte mixtures related to seawater (ionic strength $<1$ mol kg ${ }^{-1} \mathrm{H}_{2} \mathrm{O}$ ). Mar. Chem. 10, 315-333.

Dickson, A.G., Millero, F.J., 1987. A comparison of the equilibrium constants for the dissociation of carbonic acid in seawater media. Deep-Sea Res. 34, 1733-1743.

Donat, J.R., Bruland, K.W., 1990. A comparison of two voltammetric techniques for determining zinc speciation in Northeast Pacific Ocean waters. Mar. Chem. 28, 301-323.

Donat, J.R., van den Berg, C.M.G., 1992. A new cathodic stripping voltammetric method for determining organic copper complexation in sea water. Mar. Chem. 38, 69-90.

Duinker, J.C., Kramer, C.J.M., 1977. An experimental study on the speciation of dissolved zinc, cadmium, lead and copper in River Rhine and North Sea water, by differential pulsed anodic stripping voltammetry. Mar. Chem. 5, 207-228. 
Dyrssen, D., 1988. Sulfide complexation in surface seawater. Mar. Chem. 24, 143-153.

Dyrssen, D., Kremling, K., 1990. Increasing hydrogen sulfide concentration and trace metal behavior in the anoxic Baltic waters. Mar. Chem. 30, 193-204.

Dyrssen, D., Wedborg, M., 1989. The state of dissolved trace sulfide in seawater. Mar. Chem. 26, 289.

Elliott, S., 1988. Linear free energy techniques for estimation of metal-sulfide complexation constants. Mar. Chem. 24, 203213.

Elliott, S., Lu, E., Rowland, F.S., 1987. Carbonyl sulfide hydrolysid as a source of hydrogen sulfide in open ocean seawater. Geophys. Res. Lett. 14 (2), 131-134.

Emerson, S., Jacobs, L., 1982. Trace metal solubility in an anoxic fjord. Earth Planet. Sci. Lett. 60, 237-252.

Gledhill, M., van den Berg, C.M.G., 1994. Determination of complexation of iron(III) with natural organic complexing ligands in seawater using cathodic stripping voltammetry. Mar. Chem. 47, 41-54.

Goldhaber, M.B., Kaplan, I.R., 1975. Apparent dissociation constants of hydrogen sulfide in chloride solutions. Mar. Chem. 3, 83-104.

Hasle, J.R., Abdullah, M.I., 1981. Analytical fractionation of dissolved copper, lead and cadmium in coastal seawater. Mar. Chem. 10, 487-503.

Hershey, J.P., Plese, T., Millero, F.J., 1988. The $\mathrm{p} K_{1} *$ for the dissociation of $\mathrm{H}_{2} \mathrm{~S}$ in various ionic media. Geochim. Cosmochim. Acta 52, 2047-2051.

Hirose, K., Dokiya, Y., Sugimura, Y., 1982. Determination of conditional stability constants of organic copper and zinc complexes dissolved in seawater using ligand exchange method with EDTA. Mar. Chem. 11, 343-354.

Jacobs, L., Emerson, S., Skei, J., 1985. Partitioning and transport of metals across the $\mathrm{O}_{2} / \mathrm{H}_{2} \mathrm{~S}$ interface in a permanently anoxic basin: Framvaren Fjord, Norway. Geochim. Cosmochim. Acta 49, 1433-1444.

Kremling, K., 1983. The behavior of $\mathrm{Zn}, \mathrm{Cd}, \mathrm{Cu}, \mathrm{Ni}, \mathrm{Co}, \mathrm{Fe}$, and $\mathrm{Mn}$ in anoxic Baltic waters. Mar. Chem. 13, 87-108.

Leal, M.F.C., van den Berg, C.M.G., 1997. Copper(I) complexation in seawater is detected by titrations with copper(II). Aqua. Geochem., in proof.

Luther, G.W., Ferdelman, T.G., 1993. Voltammetric characterization of iron(II) sulfide complexes in laboratory solutions and in marine waters and porewaters. Environ. Sci. Technol. 27, 1154-1163.

Luther, G.W., Tsamakis, E., 1989. Concentration and form of dissolved sulfide in the oxic water column of the ocean. Mar. Chem. 27, 165-177.

Luther, G.W., Church, T.M., Powell, D., 1991. Sulfur speciation and sulfide oxidation in the water column of the Black Sea. Deep-Sea Res. 38 (2), s1121-s1137.

Luther, G.W., Rickard, D.T., Theberge, S., Olroyd, A., 1996. Determination of metal (bi)sulfide stability constants of $\mathrm{Mn}^{2+}$, $\mathrm{Fe}^{2+}, \mathrm{Co}^{2+}, \mathrm{Ni}^{2+}, \mathrm{Cu}^{2+}$ and $\mathrm{Zn}^{2+}$ by voltammetric methods. Environ. Sci. Technol. 30, 671-679.

Millero, F.J., 1991. The oxidation of $\mathrm{H}_{2} \mathrm{~S}$ in Black Sea waters. Deep-Sea Res. 38, s1139-s1150.
Millero, F.J., Leferriere, A., Fernandez, M., Hubinger, S., Hershey, J.P., 1989. Oxidation of $\mathrm{H}_{2} \mathrm{~S}$ with $\mathrm{H}_{2} \mathrm{O}_{2}$ in natural waters. Environ. Sci. Technol. 23, 209-213.

Mills, G.L., Hanson, A.K., Quinn, J.G., 1982. Chemical studies of copper-organic complexes isolated from estuarine waters using C18 reverse-phase liquid chromatography. Mar. Chem. 11, 355-377.

Morfett, K., Davison, W., Hamilton-taylor, J., 1988. Trace metal dynamics in a seasonally anoxic lake. Environ. Sci. Technol. 11 (1), 107-114.

Nürnberg, H.W., Valenta, P., 1983. Potentialities and applications of voltammetry in chemical speciation of trace metals in the sea. In: Wang, C.S., Boyle, E., Bruland, K.W., Burton, J.D. Goldberg, E.D. (Eds.), Trace Metals in Seawater. Plenum, pp. 671-697.

Radford-Knoery, J., Cutter, G.A., 1993. Determination of carbonyl sulfide and hydrogen sulfide species in natural waters using specialized collection procedures and gas chromatography with flame photometric detection. Anal. Chem. 65, 976982.

Radford-Knoery, J., Cutter, G.A., 1994. Biogeochemistry of dissolved hydrogen sulfide species and carbonyl sulfide in the Western North Atlantic Ocean. Geochim. Cosmochim. Acta 58 (24), 5421-5431.

Ringbom, A., Still, E., 1972. The calculation and use of $\alpha$-coefficients. Anal. Chim. Acta 59, 142-147.

Schwarzenbach, G., Widmer, M., 1963. Die löslichkeit von metallsulfiden: I. Schwarzes quecksilbersulfid. Helv. Chim. Acta 46, 2613-2613.

Schwarzenbach, G., Widmer, M., 1966. Die löslichkeit von metallsulfiden: II. Silbersulfid. Helv. Chem. Acta 49, 111-123.

Stary, J., Zolotov, Y.A., Petrukhin, O.M., 1979. Critical evaluation of equilibrium constants involving 8-hydroxyquinoline and its metal chelates. IUPAC Chemical Data Series, 24. Pergamon Press, Oxford, 37 pp.

Ste-Marie, J., Torma, A.E., Gubeli, A.O., 1964. The stability of thiocomplexes and solubility products of metal-sulfides: I. Cadmium sulfide. Can. J. Chem. 42, 662-668.

Turner, D.R., Whitfield, M., Dickson, A.G., 1981. The equilibrium speciation of dissolved components in freshwater and seawater at $25^{\circ} \mathrm{C}$ and 1 atm pressure. Geochim. Cosmochim. Acta 45, 855-881.

Turner, J.A., Abel, R.H., Osteryoung, R.A., 1975. Normal pulse polarographic analysis based on mercury anodization: sulfide and iodide. Anal. Chem. 47, 1343-1347.

van den Berg, C.M.G., 1984a. Determination of the complexing capacity and conditional stability constants of complexes of copper(II) with natural organic ligands in seawater by cathodic stripping voltammetry of copper-catechol complex ions. Mar. Chem. 15, 1-18.

van den Berg, C.M.G., 1984b. Organic and inorganic speciation of copper in the Irish Sea. Mar. Chem. 14, 201-212.

van den Berg, C.M.G., 1985. Determination of the zinc complexation capacity in seawater by cathodic stripping voltammetry of zinc-APDC complex ions. Mar. Chem. 16, 121-130.

van den Berg, C.M.G., 1986. Determination of copper, cadmium and lead in seawater by cathodic stripping voltammetry of 
complexes with 8-hydroxyquinoline. J. Electroanal. Chem. 215, 111-121.

van den Berg, C.M.G., Nimmo, M., 1987. Determination of interactions of nickel with dissolved organic material in seawater using cathodic stripping voltammetry. Sci. Total Environ. 60, 185-195.

van den Berg, C.M.G., Boussemart, M., Yokoi, K., Prartono, T., Campos, M.L.A.M., 1994. Speciation of aluminium, chromium and titanium in the NW Mediterranean. Mar. Chem. 45, 267-282.

van den Berg, C.M.G., 1995. Evidence for organic complexation of iron in seawater. Mar. Chem. 50, 139-157.

Vazquez, F., Zhang, J.-Z., Millero, F.J., 1989. Effect of metals on the rate of the oxidation of $\mathrm{H}_{2} \mathrm{~S}$ in seawater. Geophys. Res. Lett. 16 (12), 1363-1366.
Zhang, J.-Z., Millero, F.J., 1994. Investigation of metal-sulfide complexes in seawater using cathodic stripping square wave voltammetry. Anal. Chim. Acta 284, 497-504.

Zhang, J.-Z., Whitfield, M., 1986. Kinetics of inorganic redox reactions in seawater: I. The reduction of iodate by bisulfide. Mar. Chem. 19, 121-137.

Zhang, H., van den Berg, C.M.G., Wollast, R., 1990. The determination of interactions of cobalt(II) with organic compounds in seawater using cathodic stripping voltammetry. Mar. Chem. 28, 285-300.

Zhou, X., Wangersky, P., 1989. Study of copper-complexing organic ligands: isolation by a Sep-Pak C18 column extraction technique and characterization by chromarod thin-layer chromatography. Mar. Chem. 26, 21-40. 